\title{
NATURAL RESOURCES: ARE THEY REALLY A CURSE?
}

\author{
Alexandr Černý \\ Randall K. Filer
}
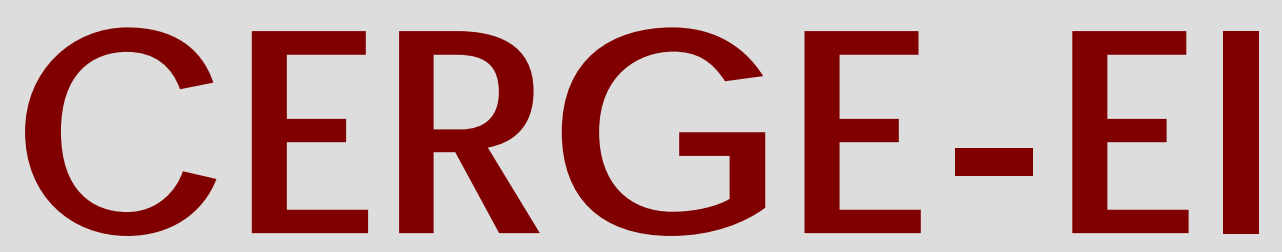

Charles University Centerfor Economic Research and Graduate Education Academy of Sciences of the Czech Republic Ec onomic s Institute 


\title{
Working Paper Series 321 (ISSN 1211-3298)
}

\section{Natural Resources: Are They Really a Curse?}

\author{
Alexandr Černý \\ Randall K. Filer
}

CERGE-EI

Prague, March 2007 
ISBN 978-80-7343-120-4 (Univerzita Karlova. Centrum pro ekonomický výzkum a doktorské studium)

ISBN 978-80-7344-109-8 (Národohospodářský ústav AV ČR, v. v. i.) 


\title{
Natural Resources: Are They Really a Curse?
}

\author{
Alexandr Černý^ and Randall K. Filer*
}

February 2006

\begin{abstract}
The curse of natural resources detected in numerous cross-country growth regressions is questioned. Although natural resource dependence is associated with slow economic growth, there is no evidence that natural resource abundance per se is negatively related to growth. Thus, the supposed link between resource dependence and growth arises not from the numerator of the dependence measures (i.e. resources themselves) but rather, because of the inherent relationship between slow growth and a small non-resource sector caused by other undetermined characteristics of the economy.
\end{abstract}

\begin{abstract}
Abstrakt
Tento článek zpochybňuje takzvané "proletí přírodních zdrojů", které bylo detekováno $\mathrm{v}$ rámci růstových regresí $\mathrm{v}$ četných studiích. Závislost na př́rodních zdrojích je sice spojena s pomalým hospodářským růstem, neexistuje však žádný důkaz o obdobném negativním vztahu mezi hospodářským růstem a skutečným přírodním bohatstvím. Dříve předpokládaná vazba mezi růstem a závislostí na přírodních zdrojích tedy nesouvisí se samotným prŕrodním bohatstvím (použitým jako čitatel v mírách závislosti), ale spíše souvisí s inherentním vztahem mezi pomalým růstem a malou velikostí sektoru výroby a služeb, přičemž tento inherentní vztah je způsoben dalšími, v růstových regresích neurčenými, charakteristikami jednotlivých ekonomik.
\end{abstract}

Keywords: Natural resources; Economic growth; Institutions

JEL Classification: O13, Q32, Q38

\footnotetext{
^ CERGE-EI is a joint workplace of the Center for Economic Research and Graduate Education, Charles University, and the Economics Institute of the ASCR, v. v. i.

Correspondence to: CERGE-EI, Politických věznů 7, 11121 Praha 1, Czech Republic.

E-mail: alexandr.cerny@cerge-ei.cz.

* Hunter College, City University of New York and CERGE-EI. E-mail: rfiler@hunter.cuny.edu.

This research was partly supported by a research center grant No. LC542 of the Ministry of Education of the Czech Republic implemented at CERGE-EI.

We wish to thank Thorvaldur Gylfason, who provided us with an electronic version of his data. Barbara Forbes, Jan Kmenta, Stepan Jurajda, Andrew Austin, Evzen Kocenda, Thorvaldur Gylfason, Richard Podpiera, and Jan Hanousek made numerous constructive and helpful comments on earlier drafts, but should not be held accountable for the opinions and conclusions presented here. All errors are ours.
} 


\section{Introduction}

Economists have long believed that natural resources (NR) constitute a fundamental requirement for economic development, but recently, it has become conventional wisdom that NR are also a curse to development. Two diverse departure points provide empirical evidence: one relies on case studies (e.g., Gelb, 1998); the other uses crosscountry growth regressions (e.g., Sachs and Warner, 1995b, 1997, and 2001, or Gylfason, 2001a, 2001b, and Gylfason and Zoega, 2002). We question the causality nature of the curse relationship arguing that the link between high NR dependence and slow economic growth results from increases in measured dependence caused by a small non-resource sector in slow-growing economies.

Figure 1 shows the relationship between economic growth and NR dependence as it is presented in the literature. It plots the average per capita GDP growth over the period 1965-1998 for 85 countries as a function of the 1994 share of natural capital in total capital (as used by Gylfason, 2001a,b and Gylfason and Zoega, 2002) and the average growth of per capita GDP over the period 1970-1990 for 86 countries as a function of the share of exports of primary products in GNP in 1970 (as used by Sachs and Warner, 1997 and also Sachs and Warner, 1995a and 2001). In both cases a surprisingly strong negative relationship between growth and NR dependence is apparent. If the measure of NR dependence is increased by one standard deviation, the average per capita growth decreases by 1.0 per cent in the first sample and by almost 0.85 per cent in the second sample. This is a serious issue, with growth averaging 1.36 per cent and 1.21 per cent, respectively in the two samples.

The existing literature offers several possible explanations for the curse rather than a general theory. ${ }^{1}$ Sachs and Warner (2001) point out that most of the explanations are based on a logic where NR crowd out a growth-inducing activity such as the tradable manufacturing sector and physical capital ("Dutch disease"), human capital, or institutional capital. Most plausible explanations also stress the role of institutions. In

\footnotetext{
${ }^{1}$ The issue of cross-country growth differences is so complex that we can hardly expect any general economic theory to fully explain it. This is also the reason why cross-country growth regressions can provide useful insights, in spite of the problems, e.g. sensitivity to sample coverage, time period, specification, and the data sources used to compute right-hand side variables and growth rates. Also, without a generally accepted growth theory, the growth regressions typically suffer from unclear causality links and related troubles with possible endogeneity of explanatory variables. Finally, the data are often very noisy and unreliable.
} 
order to inhibit economic growth, NR must be combined with bad government policies or at least with the lack of good ones.

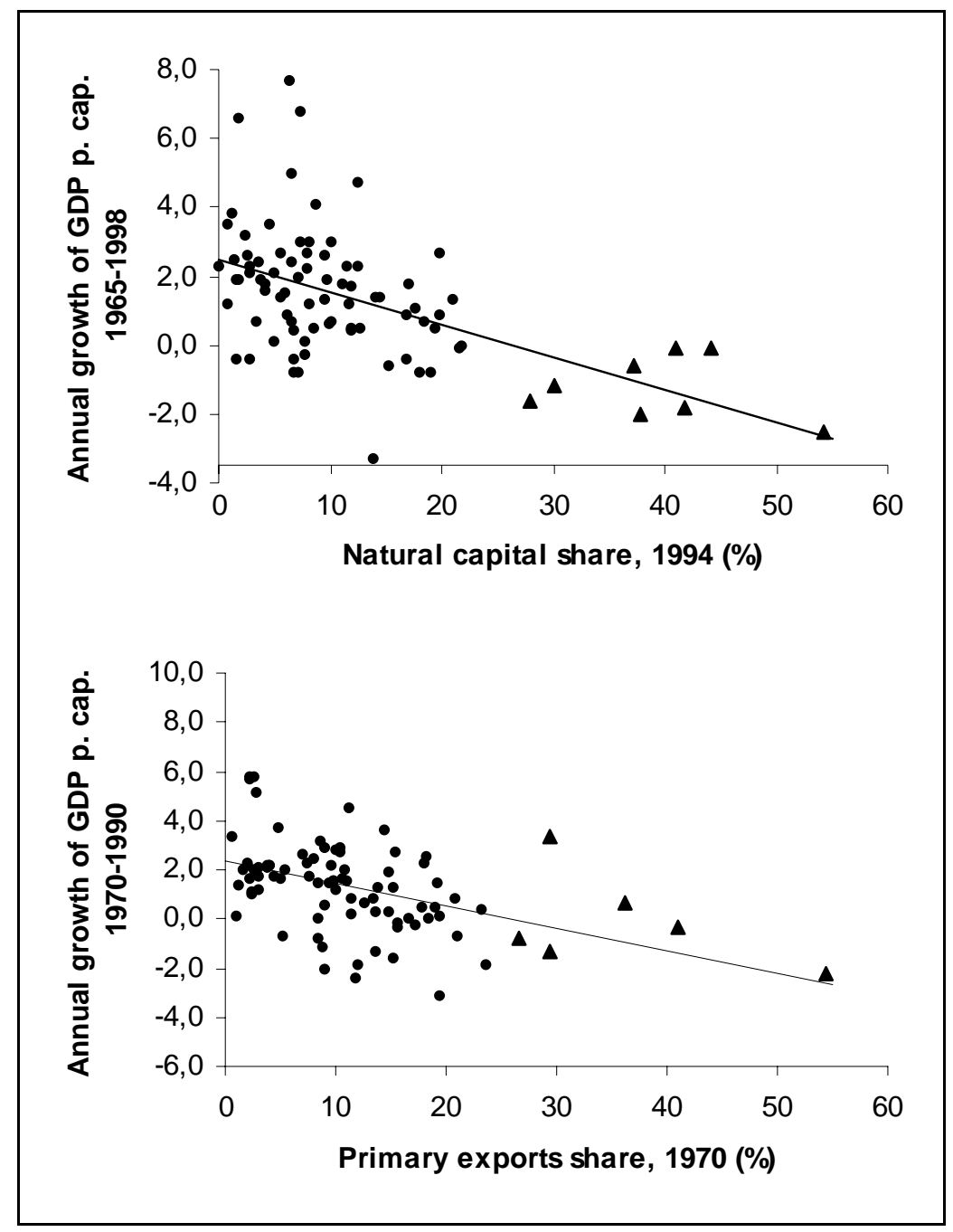

Figure 1: Economic growth and NR dependence in the Natural Capital Sample and Primary Exports Sample.

Note: Triangles represent the most NR dependent countries, which are the Central African Republic, Chad, Guinea-Bissau, Madagascar, Mali, Niger, Sierra Leone, and Zambia in the Natural Capital Sample and the Ivory Coast, Gambia, Mauritania, Mauritius, Uganda, and Zambia in the Primary Exports Sample.

Source: Gylfason (2001a,b) or Gylfason and Zoega (2002) for the Natural Capital Sample and Sachs and Warner (1997) for the Primary Exports Sample. 
When estimating resource curse cross-country growth regressions, most authors use variables that measure NR dependence or intensity rather than abundance or wealth. By replicating the regressions with the data samples used originally by Sachs and Warner and by Gylfason and Gylfason with Zoega, we confirm the robustness of the negative association between growth and NR dependence. However, we challenge the prevailing interpretation of this result. When we substitute per capita NR wealth, the results change substantially. In order to address the oft-stressed role of institutions, we also control for four different indices of the quality of democracy.

The results presented here do not provide any evidence that NR themselves are associated with slow economic growth. Apparently, the resource curse regressions capture a different statistical relationship between the structure of the economy and economic growth: the relatively small size of the non-resource sector leads to a high measure of NR dependence, and is associated with slow economic growth.

Therefore, a question of causality and particularly of a subtle "developmental bias" mentioned by Sachs and Warner (1995b, 1997, and 2001) becomes relevant. Is the small size of the non-resource sector measured by NR dependence a cause of slow growth, or is it only a result of slow growth? In other words, permanently slow-growing countries would, after a while, appear as NR dependent countries compared to permanently fast-growing countries. NR dependence measured at any time within the period studied would then be statistically associated with subsequent slow economic growth.

\section{Data}

Data used in this paper, detailed definitions of all variables, and basic statistics and correlations are in Appendix A. The first data sample, which we will henceforth refer to as the Natural Capital Sample, includes 85 countries and contains average economic indicators and indicators of the quality of democracy over the period 1965-1998. ${ }^{2}$ The

\footnotetext{
${ }^{2}$ The core variables of the Natural Capital sample were kindly provided by Thorvaldur Gylfason, who previously used them in his research; see Gylfason (2001a,b) and Gylfason and Zoega (2002). The data are also available in Gylfason and Zoega (2002). The main original source of the data is the World Development Indicators 2000 CD. Only the estimates of natural capital are taken from World Bank (1997).
} 
second sample, henceforth the Primary Exports Sample, covers 86 countries and the period 1970-1990. ${ }^{3}$

The core variables of the Natural Capital Sample include the average annual growth of real per capita GDP over the period 1965-1998 (economic growth), the indicator of NR dependence measured by the share of natural capital in total capital i.e., natural, human, and physical capital in 1994 (natural capital share), natural logarithm of 1965 per capita GNP (log initial income), the average gross domestic investment as percentage of GDP over the period 1965-1998 (investment ratio), and the average secondary school enrollment rate computed over the same period (enrollment rate).

The core variables of the Primary Exports Sample include the average annual growth of real GDP divided by the economically active population over the period 1970-1990 (economic growth), the indicator of NR dependence measured by the share of exports of primary products in GNP in 1970 (primary exports share), natural logarithm of real GDP divided by the economically active population in 1970 (log initial income), the fraction of years during the period 1970-1990 in which the country is rated as an open economy as defined in Sachs and Warner (1995b) (openness), and the natural logarithm of the ratio of real gross domestic investment to real GDP, averaged over the period 1970-1989 (log investment ratio).

Additionally, we construct the measures of NR abundance in both samples. These are defined as the per capita exports of primary products in 1970 (primary exports per capita) in the Primary Exports Sample and as per capita value of natural capital in 1994 (natural capital per capita) in the Natural Capital Sample. These variables are described in the following section.

Both samples are further extended by measures of the quality of democracy (autocracy, democracy, civil liberties, and political rights) taken from two distinct sources. The indices of autocracy and democracy are from the Polity IV 2001 data set. $^{4}$

\footnotetext{
${ }^{3}$ The core variables of the Primary Exports Sample are taken from the dataset used in Sachs and Warner (1997). The data are available at http://www.cid.harvard.edu/. Sachs and Warner also used them with minor modifications in their subsequent papers (1995a and 2001). The main original source of the data are Penn World Tables, mark 5.6. Only primary exports share and log initial income are computed with the use of the World Bank World Data 1995 CD. With some variables and for some particular country observations, Sachs and Warner use additional data sources and eventually also different years of measurement than those given in the basic definitions. For a detailed description and definitions of all variables see Appendix A of this paper and the description of variables in Sachs and Warner (1997).

${ }^{4}$ A detailed methodology used to assign these indices is described in Polity IV Project (2001) and Marshall and Jaggers (2002).
} 
These indices correspond to the variables AUTOC and DEMOC in the original data set. They sort countries into eleven groups for each year. The 0 value corresponds to the lowest level of autocracy and democracy, respectively. The value 10 indicates the toughest autocratic regime for the autocracy index, and the highest level of democracy for the democracy index. In this paper the indices are divided by 10, which transform them into a range between 0 and 1 . In both samples, democracy and autocracy indices stand for averages of the individual yearly values over the respective time periods. Some yearly observations are missing for a few countries, in which case only the available observations are used.

The indices of civil liberties and political rights come from the Freedom House country ratings. ${ }^{5}$ Every year Freedom House ranks countries into seven categories with 1 corresponding to the highest and 7 to the lowest level of civil liberties or political rights. For the purposes of this paper, both indices are converted to a scale from 0 to 1 , where 0 corresponds to the lowest and 1 to the highest level. Since the Freedom House indices are only available starting in 1973, for the Natural Capital Sample, which runs from 1965 to 1998, we take for each country the average of available observations from 1973 to 1998. In the Primary Exports Sample, which runs from 1970 to 1990, we use the average of available observations over the period 1973-1990.

Not surprisingly, the four measures of the quality of democracy are highly correlated in both samples. The two indices that differ the most are autocracy and civil liberties, but their correlation coefficient is still very high $(-0.88$ in the Natural Capital Sample and -0.90 in the Primary Exports Sample.)

Table 1: Correlations of selected variables between Natural Capital Sample and Primary Exports Sample.

\begin{tabular}{lrrrr}
\hline \hline \multicolumn{1}{c}{74 observations } & \multicolumn{2}{c}{ Sample 1965-1998 } \\
\multicolumn{1}{c}{ Sample 1970-1990 } & $\begin{array}{r}\text { Economic } \\
\text { growth }\end{array}$ & $\begin{array}{r}\text { Nat. capital } \\
\text { share }\end{array}$ & $\begin{array}{r}\text { Nat. Capital } \\
\text { p. cap. }\end{array}$ & $\begin{array}{r}\text { Log initial } \\
\text { income }\end{array}$ \\
\hline Economic growth & 0.88 & & & \\
Primary exports share & & 0.38 & -0.01 & \\
Primary exports . cap. & & -0.19 & 0.59 & 0.93 \\
Log initial income & & & & \\
\hline \hline
\end{tabular}

Note: Only 74 overlapping country observations can be used in both samples.

\footnotetext{
${ }^{5}$ For a detailed description of the methodology used to assign each index, see Freedom House (2002). Freedom House indices are quite popular in empirical economic research and were previously used, for example, by Helliwell (1992), Barro (1999), or Easterly (2001).
} 
With both samples, we employ the same set of countries as Gylfason, and Sachs and Warner, except for excluding Hong Kong from the Primary Exports Sample, because measures of the quality of democracy are not available. This exclusion changes the results only negligibly. In addition, primary exports per capita are missing from Primary Exports Sample for Germany, Iran, and Taiwan. When comparing the results of different regressions in the Primary Exports Sample or across the two samples, various country observations can be missing. Therefore, we always refer also to results using only identical country observations. This issue is important given that numerous crosscountry growth regressions have been found to be sensitive to sample coverage (e.g., Levine and Renelt, 1992). Surprisingly, many researchers who study the curse of natural resources neglect this issue and compare regressions' results that employ samples of notably different coverage (e.g. Sachs and Warner, 1997).

In addition to the sample coverage, results of cross-country growth regressions can be sensitive to time period, specification, and the data source used to compute both right-hand-side variables and growth rates (see, for example, Hanousek et al., 2004). Thus, many potentially important differences exist between the two samples employed here. Nevertheless, the major difference between the Natural Capital and Primary Exports Samples seems to rest in the use of different measures of NR dependence and abundance. Table 1 shows correlations of selected corresponding economic variables between the two samples when reduced to 74 overlapping countries. The lowest are the correlations between natural capital per capita and primary exports per capita, which is only 0.59 , and between natural capital share and primary exports share, which is only 0.38 . In spite of this, the nature of all major results presented below is almost the same, independent of which sample is used.

\section{Measures of NR Dependence and Abundance}

When studying the resource curse most authors ${ }^{6}$ use the share of primary product exports or mineral production in either GNP or total exports in order to measure the effect of NR. Typically, this variable is computed for the initial year of the period over which growth rates are computed. To our knowledge, Gylfason (2001a,b) and Gylfason 
and Zoega (2002) are the only researchers who use the share of natural capital in total capital. This measure is taken from a World Bank (1997) study that attempts to estimate the value of natural capital for 92 countries. The value of natural capital comprises the value of pastureland, cropland, timber resources, non-timber forest resources, protected areas, and subsoil assets. Since 1994 is the only year for which this estimate is available, it is impossible to employ the share of natural capital in total capital in the sample's initial year, 1965 .

Both measures, indicate NR dependence rather than abundance, because they are expressed as ratios of NR abundance to the total performance of the economy. To investigate if natural resources are really associated with slow growth, we focus on truely exogenous NR abundance, in each of the two samples. The resulting pairs of variables estimating NR dependence versus abundance are natural capital share versus natural capital per capita in the Natural Capital Sample and primary exports share versus primary exports per capita in the Primary Exports Sample.

Natural capital per capita is taken directly from World Bank (1997) and includes the per capita value of pastureland, cropland, timber resources, non-timber forest resources, and subsoil assets in 1994. The estimated value of protected areas is excluded, because protected areas in part represent an achievement of developed industrial countries and, as such, do not approximate exogenous natural wealth properly. ${ }^{7}$ To make the coefficient estimates directly comparable to earlier work, natural capital per capita is further multiplied by an appropriate constant so that the sample maximum of natural capital per capita equals the sample maximum of natural capital share.

Primary exports per capita are computed by multiplying primary exports share by the 1970 per capita GNP measured in constant 1995 U.S dollars as reported by the World Bank (2000). ${ }^{8}$ Primary exports per capita are also multiplied by a constant such that the maxima of primary exports per capita and primary exports share are equal.

\footnotetext{
${ }^{6}$ E.g., Sachs and Warner, 1995b, 1997, and 2001, Mehlum et al. (2002), or Papyrakis and Gerlagh (2004).

${ }^{7}$ The results presented in this paper do not change when the value of protected areas is included. The results also remain nearly the same if only the per capita value of subsoil assets is taken into account.

${ }^{8}$ In some cases Sachs and Warner use years other than 1970 to compute the variable named primary exports share here. We follow these exceptions and use the same years for GNP per capita when transforming primary exports share to primary exports per capita.
} 


\section{Empirical Results}

\subsection{NR Dependence and Economic Growth}

First, we replicate earlier work by using NR dependence in cross-country growth regressions. We also investigate whether the estimates of resource effects remain negative and significant when controlling for the four democracy indicators.

Table 2 reports the OLS estimates of the curse in the Natural Capital Sample. For comparison purposes, we reestimate two regressions presented in Gylfason (2001), regressing economic growth on natural capital share, log initial income, investment ratio, and enrollment rate, and the same regression excluding the enrollment rate. Additionally, we also include regression of economic growth on natural capital share and log initial income and the simplest regression of economic growth on natural capital share alone. The coefficient estimates in the first two equations are very close to those reported in Gylfason (2001). ${ }^{9}$ The coefficient for natural capital share is significant and negative in all four estimated equations. It remains almost unchanged when four different measures of the quality of democracy are included. These results are in line with the reported robustness of the curse of natural resources. The four different indices of the quality of democracy appear significant in most of the estimated equations, with the expected sign supporting the idea that democracy and growth are correlated. Of course, it is not possible to decide the relationship's direction of causality in this case.

\footnotetext{
${ }^{9}$ A negligible difference is present due to the fact that Gylfason estimated the equations in a seemingly unrelated regressions system.
} 
Table 2: OLS estimates of the natural resource curse for Natural Capital Sample using share of natural capital in total capital as the measure of NR dependence.

Dependent variable is economic growth.

\begin{tabular}{|c|c|c|c|c|c|c|}
\hline \multicolumn{7}{|c|}{ OLS method; Obs. 85} \\
\hline Constant & $\begin{array}{r}\text { Natural } \\
\text { capital share }\end{array}$ & $\begin{array}{r}\text { Log initial } \\
\text { income }\end{array}$ & $\begin{array}{r}\text { Investment } \\
\text { ratio }\end{array}$ & $\begin{array}{r}\text { Enrollment } \\
\text { rate }\end{array}$ & $X$ & $\mathrm{R}^{2}$ \\
\hline $10.1(5.79)$ & $-0.07(4.60)$ & $-1.54(7.05)$ & $0.10(3.43)$ & $0.05(5.36)$ & & 0.67 \\
\hline${ }^{\mathrm{a}} 3.51(2.45)$ & $-0.08(5.30)$ & $-0.60(3.97)$ & $0.18(5.92)$ & & & 0.55 \\
\hline $7.29(4.77)$ & $-0.12(6.74)$ & $-0.58(3.20)$ & & & & 0.36 \\
\hline $2.47(9.29)$ & $-0.09(5.63)$ & & & & & 0.28 \\
\hline \multicolumn{7}{|l|}{$X=$ Autocracy } \\
\hline $12.5(7.01)$ & $-0.06(4.66)$ & $-1.73(8.13)$ & $0.10(3.57)$ & $0.04(4.89)$ & $-1.98(3.43)$ & 0.71 \\
\hline $7.59(4.55)$ & $-0.08(5.26)$ & $-0.99(5.83)$ & $0.16(5.84)$ & & $-2.56(3.99)$ & 0.63 \\
\hline $11.8(6.61)$ & $-0.11(6.52)$ & $-1.05(5.20)$ & & & $-3.07(4.07)$ & 0.47 \\
\hline $2.62(8.87)$ & $-0.09(4.66)$ & & & & ${ }^{\mathrm{c}}-0.82(1.16)$ & 0.29 \\
\hline \multicolumn{7}{|c|}{$X=$ Democracy } \\
\hline $11.5(6.69)$ & $-0.07(4.85)$ & $-1.74(8.03)$ & $0.10(3.42)$ & $0.04(4.40)$ & $1.56(3.15)$ & 0.71 \\
\hline $7.14(4.59)$ & $-0.08(5.49)$ & $-1.14(6.11)$ & $0.14(5.37)$ & & $2.24(4.28)$ & 0.63 \\
\hline $11.2(7.13)$ & $-0.11(6.68)$ & $-1.27(5.95)$ & & & $2.88(4.88)$ & 0.50 \\
\hline $2.12(4.88)$ & $-0.09(4.64)$ & & & & ${ }^{\mathrm{c}} 0.54(1.03)$ & 0.29 \\
\hline \multicolumn{7}{|c|}{$X=$ Civil liberties } \\
\hline $11.9(6.92)$ & $-0.06(4.85)$ & $-1.88(8.27)$ & $0.09(3.33)$ & $0.04(4.33)$ & $2.72(3.46)$ & 0.71 \\
\hline $7.78(4.91)$ & $-0.08(5.45)$ & $-1.34(6.38)$ & $0.14(5.18)$ & & $3.79(4.60)$ & 0.65 \\
\hline $11.9(7.56)$ & $-0.10(6.58)$ & $-1.54(6.49)$ & & & $4.91(5.38)$ & 0.53 \\
\hline $2.16(3.73)$ & $-0.09(4.68)$ & & & & ${ }^{\mathrm{c}} 0.44(0.60)$ & 0.28 \\
\hline \multicolumn{7}{|c|}{$X=$ Political rights } \\
\hline $11.8(7.06)$ & $-0.06(4.67)$ & $-1.85(8.52)$ & $0.09(3.20)$ & $0.04(4.60)$ & $2.38(3.86)$ & 0.72 \\
\hline $7.26(4.82)$ & $-0.08(5.22)$ & $-1.23(6.46)$ & $0.14(5.12)$ & & $3.11(4.69)$ & 0.65 \\
\hline $11.2(7.51)$ & $-0.10(6.25)$ & $-1.40(6.51)$ & & & $4.04(5.52)$ & 0.53 \\
\hline $1.93(3.54)$ & $-0.08(4.39)$ & & & & ${ }^{\mathrm{c}} 0.72(1.13)$ & 0.29 \\
\hline
\end{tabular}

Notes: Absolute values of t-statistics are in parenthesis. All the estimated coefficients are significant at the $1 \%$ significance level. Exceptions: ${ }^{a}$ significant at $5 \%$; ${ }^{b}$ significant at $10 \%{ }^{c}$ insignificant at $10 \%$. 
Table 3: OLS estimates of the natural resource curse for Primary Exports Sample using share of exports of primary products in GNP as the measure of NR dependence. Dependent variable is economic growth.

\begin{tabular}{|c|c|c|c|c|c|c|}
\hline \multicolumn{7}{|c|}{ OLS method; Obs. 86} \\
\hline \multirow[b]{2}{*}{ Constant } & \multirow{2}{*}{$\begin{array}{r}\text { Primary } \\
\text { exports share }\end{array}$} & \multirow{2}{*}{$\begin{array}{r}\text { Log initial } \\
\text { income }\end{array}$} & \multicolumn{3}{|c|}{ Log investment } & \multirow[b]{2}{*}{$\mathrm{R}^{2}$} \\
\hline & & & Openness & ratio & $X$ & \\
\hline $8.94(7.05)$ & $-0.07(5.55)$ & $-1.34(7.89)$ & $2.34(6.90)$ & $1.26(5.79)$ & & 0.68 \\
\hline $8.78(5.85)$ & $-0.07(4.48)$ & $-0.95(5.16)$ & $2.99(7.89)$ & & & 0.55 \\
\hline $\mathrm{b}_{3.35(1.91)}$ & $-0.09(4.63)$ & ${ }^{c}-0.13(0.64)$ & & & & 0.21 \\
\hline $2.24(8.01)$ & $-0.09(4.67)$ & & & & & 0.21 \\
\hline \multicolumn{7}{|l|}{$X=$ Autocracy } \\
\hline $8.93(5.51)$ & $-0.07(5.51)$ & $-1.33(6.78)$ & $2.34(6.67)$ & $1.26(5.75)$ & ${ }^{\mathrm{c}} 0.005(0.01)$ & 0.68 \\
\hline $8.43(4.41)$ & $-0.07(4.44)$ & $-0.92(4.24)$ & $3.01(7.70)$ & & ${ }^{\mathrm{c}} 0.17(0.29)$ & 0.55 \\
\hline $5.31(2.17)$ & $-0.09(4.62)$ & ${ }^{\mathrm{c}}-0.33(1.24)$ & & & ${ }^{\mathrm{c}}-0.84(1.15)$ & 0.22 \\
\hline $2.31(7.22)$ & $-0.09(4.45)$ & & & & c $-0.25(0.45)$ & 0.21 \\
\hline \multicolumn{7}{|c|}{$X=$ Democracy } \\
\hline $9.03(5.74)$ & $-0.07(5.48)$ & $-1.35(6.40)$ & $2.33(6.53)$ & $1.25(5.75)$ & ${ }^{\mathrm{c}} 0.04(0.10)$ & 0.68 \\
\hline $9.06(4.87)$ & $-0.07(4.45)$ & $-0.99(4.15)$ & $2.95(7.36)$ & & ${ }^{\mathrm{c}} 0.14(0.26)$ & 0.55 \\
\hline $6.76(2.88)$ & $-0.09(4.85)$ & a $-0.60(2.03)$ & & & ${ }^{\mathrm{a}} 1.35(2.12)$ & 0.25 \\
\hline $2.04(5.65)$ & $-0.08(4.41)$ & & & & ${ }^{c} 0.38(0.89)$ & 0.21 \\
\hline \multicolumn{7}{|c|}{$X=$ Civil liberties } \\
\hline $9.17(5.97)$ & $-0.07(5.51)$ & $-1.37(6.21)$ & $2.31(6.39)$ & $1.26(5.77)$ & ${ }^{\mathrm{c}} 0.18(0.27)$ & 0.68 \\
\hline $8.74(4.82)$ & $-0.07(4.43)$ & $-0.94(3.82)$ & $2.99(7.41)$ & & ${ }^{\mathrm{c}}-0.03(0.03)$ & 0.55 \\
\hline $6.36(2.77)$ & $-0.09(4.77)$ & ${ }^{b}-0.61(1.94)$ & & & ${ }^{\mathrm{b}} 1.84(1.98)$ & 0.25 \\
\hline $1.97(4.22)$ & $-0.08(4.39)$ & & & & ${ }^{\mathrm{c}} 0.44(0.73)$ & 0.21 \\
\hline \multicolumn{7}{|c|}{$X=$ Political rights } \\
\hline $9.63(6.15)$ & $-0.07(5.57)$ & $-1.44(6.55)$ & $2.27(6.45)$ & $1.25(5.75)$ & ${ }^{\mathrm{c}} 0.44(0.76)$ & 0.68 \\
\hline $9.61(5.20)$ & $-0.07(4.51)$ & $-1.08(4.32)$ & $2.90(7.33)$ & & ${ }^{\mathrm{c}} 0.53(0.77)$ & 0.55 \\
\hline $6.99(3.00)$ & $-0.09(4.77)$ & a $-0.69(2.21)$ & & & ${ }^{\mathrm{a}} 1.93(2.31)$ & 0.26 \\
\hline $1.93(4.34)$ & $-0.08(4.33)$ & & & & ${ }^{\mathrm{c}} 0.48(0.91)$ & 0.21 \\
\hline
\end{tabular}

Notes: Absolute values of t-statistics are in parenthesis. All the estimated coefficients are significant at the $1 \%$ significance level. Exceptions: ${ }^{\mathrm{a}}$ significant at $5 \%$; ${ }^{\mathrm{b}}$ significant at $10 \%$; ${ }^{\mathrm{c}}$ insignificant at $10 \%$.

In Table 3, we present the results of the OLS estimates for the Primary Exports Sample, replicating the three basic regressions in Sachs and Warner (1995a and 1997). We also include the simplest regression of economic growth on primary exports share. The coefficient estimates in the first three equations are very close to those reported in Sachs and Warner (1995a and 1997). ${ }^{10}$ The robustness of the resource curse result is again confirmed. The coefficient for primary exports share is significant and negative in all four estimated equations and it survives, with only minor changes, the inclusion of the four different measures of the quality of democracy. The coefficient estimates for the indices of the quality of democracy have the expected signs, supporting the idea that democracy is associated with economic growth. However, unlike the results in the

\footnotetext{
${ }^{10}$ A negligible difference is present due to the fact that, unlike Sachs and Warner, we exclude Hong Kong from the sample.
} 
Natural Capital Sample, the autocracy index is insignificant in all four equations, while the indices of democracy, civil liberties, and political rights are significant only at the 5 per cent or 10 per cent level and only in the regression of economic growth on primary exports share and log initial income. These differences can be partly explained by the inclusion of a measure of openness in the Primary Exports Sample. Openness can be also interpreted as a measure of the institutional environment.

\subsection{NR Abundance and Economic Growth}

To see the effect of pure NR wealth on growth, we estimate regressions identical to those in the previous section, but replace natural capital share in the Natural Capital Sample with natural capital per capita, and primary exports share in the Primary Exports Sample with primary exports per capita. That is, measures of NR dependence are replaced by measures of NR abundance. Simple correlations suggest that we can expect radically different results. Natural capital per capita with natural capital share and primary exports per capita with primary exports share are almost uncorrelated. (The correlation coefficients are only 0.12 and 0.03 respectively.) Also, in contrast to the strong negative correlation of natural capital share and primary exports share with economic growth, very low positive correlations are detected between economic growth and natural capital per capita or primary exports per capita. (Both correlation coefficients are only 0.05 .)

Regression results using the Natural Capital Sample are reported in Table 4, results for the Primary Exports Sample in Table 5. ${ }^{11}$ The coefficient for natural capital per capita and primary exports per capita is close to zero and insignificant in all the estimated equations. To further confirm this result, we reduce both samples to the 74 overlapping country-observations and estimate the four basic equations in each sample by using different measures of NR dependence and abundance. The results presented in Tables 6 and 7 are clear. While natural capital share and primary exports share are significantly negatively related to growth in all equations, natural capital per capita and primary exports per capita are not significant, with coefficient values close to zero in all equations in both samples. 
Table 4: OLS estimates of the natural resource curse for Natural Capital Sample using natural capital per capita as the measure of NR abundance.

Dependent variable is economic growth.

\begin{tabular}{|c|c|c|c|c|c|c|}
\hline \multicolumn{7}{|c|}{ OLS method; Obs. 85} \\
\hline Constant & $\begin{array}{r}\text { Natural } \\
\text { capital p. cap. }\end{array}$ & $\begin{array}{r}\text { Log initial } \\
\text { income }\end{array}$ & $\begin{array}{r}\text { Investment } \\
\text { ratio }\end{array}$ & $\begin{array}{r}\text { Enrollment } \\
\text { rate }\end{array}$ & $X$ & $\mathrm{R}^{2}$ \\
\hline $8.10(4.19)$ & ${ }^{\mathrm{c}}-0.00(0.06)$ & $-1.50(5.97)$ & $0.13(3.89)$ & $0.06(5.98)$ & & 0.58 \\
\hline${ }^{\mathrm{c}}-1.10(0.78)$ & ${ }^{\mathrm{c}} 0.01(0.25)$ & ${ }^{\mathrm{c}}-0.30(1.64)$ & $0.23(7.24)$ & & & 0.40 \\
\hline${ }^{\mathrm{c}} 1.99(1.17)$ & ${ }^{\mathrm{c}} 0.02(0.62)$ & ${ }^{\mathrm{c}}-0.10(0.43)$ & & & & 0.00 \\
\hline $1.27(4.39)$ & ${ }^{\mathrm{c}} 0.01(0.47)$ & & & & & 0.00 \\
\hline \multicolumn{7}{|l|}{$X=$ Autocracy } \\
\hline $10.67(5.40)$ & ${ }^{\mathrm{c}}-0.01(0.35)$ & $-1.69(6.93)$ & $0.12(4.01)$ & $0.05(5.45)$ & $-2.17(3.33)$ & 0.63 \\
\hline a $3.90(2.17)$ & ${ }^{\mathrm{c}}-0.00(0.11)$ & $-0.75(3.73)$ & $0.21(7.01)$ & & $-2.96(3.99)$ & 0.50 \\
\hline $8.20(3.86)$ & ${ }^{\mathrm{c}} 0.00(0.21)$ & $-0.72(2.86)$ & & & $-3.92(4.25)$ & 0.19 \\
\hline $2.24(5.32)$ & ${ }^{\mathrm{c}}-0.02(0.70)$ & & & & $-2.39(3.05)$ & 0.10 \\
\hline \multicolumn{7}{|c|}{$X=$ Democracy } \\
\hline $9.35(4.90)$ & ${ }^{\mathrm{c}}-0.01(0.38)$ & $-1.69(6.73)$ & $0.12(3.88)$ & $0.05(5.03)$ & $1.58(2.78)$ & 0.62 \\
\hline${ }^{b} 3.00(1.83)$ & ${ }^{\mathrm{c}}-0.00(0.24)$ & $-0.87(3.99)$ & $0.20(6.54)$ & & $2.48(4.03)$ & 0.50 \\
\hline $7.22(3.90)$ & ${ }^{\mathrm{c}}-0.00(0.01)$ & $-0.96(3.58)$ & & & $3.55(4.85)$ & 0.23 \\
\hline${ }^{\mathrm{a}} 0.68(2.06)$ & ${ }^{\mathrm{c}}-0.02(0.88)$ & & & & $1.81(3.09)$ & 0.11 \\
\hline \multicolumn{7}{|c|}{$X=$ Civil liberties } \\
\hline $9.78(5.13)$ & ${ }^{\mathrm{c}}-0.01(0.61)$ & $-1.83(7.04)$ & $0.12(3.80)$ & $0.05(4.95)$ & $2.87(3.17)$ & 0.63 \\
\hline${ }^{\mathrm{a}} 3.80(2.27)$ & ${ }^{\mathrm{c}}-0.01(0.54)$ & $-1.10(4.52)$ & $0.19(6.30)$ & & $4.32(4.42)$ & 0.51 \\
\hline $8.22(4.44)$ & ${ }^{\mathrm{c}}-0.01(0.38)$ & $-1.31(4.44)$ & & & $6.19(5.48)$ & 0.28 \\
\hline${ }^{\mathrm{c}} 0.21(0.47)$ & ${ }^{\mathrm{c}}-0.02(0.98)$ & & & & $2.43(2.94)$ & 0.10 \\
\hline \multicolumn{7}{|c|}{$X=$ Political rights } \\
\hline $9.97(5.37)$ & ${ }^{\mathrm{c}}-0.01(0.42)$ & $-1.83(7.35)$ & $0.11(3.63)$ & $0.05(5.13)$ & $2.62(3.77)$ & 0.65 \\
\hline a $3.67(2.30)$ & ${ }^{\mathrm{c}}-0.00(0.23)$ & $-1.03(4.63)$ & $0.19(6.12)$ & & $3.63(4.74)$ & 0.53 \\
\hline $7.89(4.54)$ & ${ }^{\mathrm{c}}-0.00(0.03)$ & $-1.21(4.53)$ & & & $5.17(5.94)$ & 0.31 \\
\hline${ }^{\mathrm{c}} 0.20(0.49)$ & ${ }^{\mathrm{c}}-0.02(1.05)$ & & & & $2.41(3.49)$ & 0.13 \\
\hline
\end{tabular}

Notes: Absolute values of t-statistics are in parenthesis. All the estimated coefficients are significant at the $1 \%$ significance level. Exceptions: ${ }^{\text {a }}$ significant at $5 \%$; ${ }^{\mathrm{b}}$ significant at $10 \%$; ${ }^{\mathrm{c}}$ insignificant at $10 \%$.

\footnotetext{
${ }^{11}$ The sample 1970-1990 is reduced to 83 observations because the data on primary exports per capita are missing for Germany, Iran, and Taiwan.
} 
Table 5: OLS estimates of the natural resource curse for Primary Exports Sample using exports of primary products per capita as the measure of NR abundance.

Dependent variable is economic growth.

\begin{tabular}{|c|c|c|c|c|c|c|}
\hline \multicolumn{7}{|c|}{ OLS method; Obs. 83} \\
\hline \multirow[b]{2}{*}{ Constant } & \multirow{2}{*}{$\begin{array}{r}\text { Primary } \\
\text { exports p. cap. }\end{array}$} & \multirow{2}{*}{$\begin{array}{r}\text { Log initial } \\
\text { income }\end{array}$} & \multicolumn{3}{|c|}{ Log investment } & \multirow[b]{2}{*}{$\mathrm{R}^{2}$} \\
\hline & & & Openness & ratio & $X$ & \\
\hline $5.27(3.16)$ & ${ }^{\mathrm{c}}-0.02(1.18)$ & $-0.97(4.27)$ & $2.53(6.33)$ & $1.20(4.82)$ & & 0.55 \\
\hline $5.27(2.80)$ & ${ }^{\mathrm{c}}-0.02(1.00)$ & ${ }^{\mathrm{a}}-0.62(2.53)$ & $3.13(7.31)$ & & & 0.41 \\
\hline${ }^{\mathrm{c}}-0.59(0.27)$ & ${ }^{\mathrm{c}}-0.00(0.16)$ & ${ }^{\mathrm{c}} 0.22(0.79)$ & & & & 0.01 \\
\hline $1.13(5.00)$ & ${ }^{\mathrm{c}} 0.01(0.48)$ & & & & & 0.00 \\
\hline \multicolumn{7}{|l|}{$X=$ Autocracy } \\
\hline${ }^{\mathrm{a}} 5.15(2.52)$ & ${ }^{\mathrm{c}}-0.02(1.16)$ & $-0.96(3.76)$ & $2.54(6.18)$ & $1.20(4.78)$ & ${ }^{\mathrm{c}} 0.06(0.10)$ & 0.55 \\
\hline${ }^{\mathrm{a}} 4.96(2.15)$ & ${ }^{\mathrm{c}}-0.02(0.96)$ & ${ }^{\mathrm{a}}-0.59(2.13)$ & $3.15(7.16)$ & & ${ }^{\mathrm{c}} 0.16(0.24)$ & 0.41 \\
\hline${ }^{\mathrm{c}} 1.23(0.43)$ & ${ }^{\mathrm{c}}-0.01(0.25)$ & ${ }^{\mathrm{c}} 0.03(0.10)$ & & & ${ }^{\mathrm{c}}-0.82(0.98)$ & 0.02 \\
\hline $1.53(3.90)$ & ${ }^{\mathrm{c}}-0.00(0.23)$ & & & & ${ }^{\mathrm{c}}-0.86(1.26)$ & 0.02 \\
\hline \multicolumn{7}{|c|}{$X=$ Democracy } \\
\hline $5.07(2.65)$ & ${ }^{\mathrm{c}}-0.02(1.11)$ & $-0.94(3.61)$ & $2.55(6.15)$ & $1.20(4.79)$ & ${ }^{\mathrm{c}}-0.12(0.21)$ & 0.55 \\
\hline${ }^{\mathrm{a}} 5.40(2.49)$ & ${ }^{\mathrm{c}}-0.02(0.99)$ & ${ }^{\mathrm{a}}-0.63(2.21)$ & $3.12(6.94)$ & & ${ }^{\mathrm{c}} 0.07(0.12)$ & 0.41 \\
\hline${ }^{\mathrm{c}} 2.07(0.77)$ & ${ }^{\mathrm{c}}-0.01(0.54)$ & ${ }^{\mathrm{c}}-0.16(0.46)$ & & & ${ }^{\mathrm{b}} 1.28(1.71)$ & 0.05 \\
\hline $0.84(3.12)$ & ${ }^{\mathrm{c}}-0.02(0.76)$ & & & & ${ }^{\mathrm{b}} 1.06(1.84)$ & 0.04 \\
\hline \multicolumn{7}{|c|}{$X=$ Civil liberties } \\
\hline $5.14(2.71)$ & ${ }^{\mathrm{c}}-0.02(1.12)$ & $-0.95(3.44)$ & $2.54(6.08)$ & $1.20(4.78)$ & ${ }^{\mathrm{c}}-0.12(0.15)$ & 0.55 \\
\hline${ }^{\mathrm{a}} 5.03(2.34)$ & ${ }^{\mathrm{c}}-0.02(0.92)$ & b-0.57(1.92) & $3.17(7.04)$ & & ${ }^{\mathrm{c}}-0.22(0.25)$ & 0.41 \\
\hline${ }^{\mathrm{c}} 1.58(0.60)$ & ${ }^{\mathrm{c}}-0.01(0.48)$ & ${ }^{\mathrm{c}}-0.14(0.38)$ & & & ${ }^{\mathrm{c}} 1.58(1.44)$ & 0.04 \\
\hline${ }^{\mathrm{c}} 0.58(1.42)$ & ${ }^{\mathrm{c}}-0.01(0.63)$ & & & & ${ }^{\mathrm{c}} 1.30(1.60)$ & 0.03 \\
\hline \multicolumn{7}{|c|}{$X=$ Political rights } \\
\hline $5.81(2.97)$ & ${ }^{\mathrm{c}}-0.02(1.23)$ & $-1.06(3.80)$ & $2.48(6.02)$ & $1.19(4.76)$ & ${ }^{\mathrm{c}} 0.38(0.54)$ & 0.55 \\
\hline $6.09(2.76)$ & ${ }^{\mathrm{c}}-0.02(1.07)$ & ${ }^{\mathrm{a}}-0.75(2.45)$ & $3.05(6.87)$ & & ${ }^{\mathrm{c}} 0.57(0.72)$ & 0.41 \\
\hline${ }^{\mathrm{c}} 2.72(1.00)$ & ${ }^{\mathrm{c}}-0.01(0.44)$ & ${ }^{\mathrm{c}}-0.30(0.81)$ & & & ${ }^{\mathrm{a}} 1.94(2.01)$ & 0.06 \\
\hline${ }^{\mathrm{c}} 0.54(1.50)$ & ${ }^{\mathrm{c}}-0.02(0.81)$ & & & & ${ }^{\mathrm{a}} 1.40(2.01)$ & 0.05 \\
\hline
\end{tabular}

Notes: Absolute values of t-statistics are in parenthesis. All the estimated coefficients are significant at the $1 \%$ significance level. Exceptions: ${ }^{\mathrm{a}}$ significant at $5 \%$; ${ }^{\mathrm{b}}$ significant at $10 \%$; ${ }^{\mathrm{c}}$ insignificant at $10 \%$.

In short, while NR dependence, measured either by natural capital share or primary exports share, is clearly associated with slower economic growth, no relationship exists between economic growth and NR abundance per se, whether measured by natural capital per capita or by primary exports per capita. The insignificant coefficient for natural capital per capita becomes positive and significant at the 1 per cent level if both natural capital share and natural capital per capita are included in all the estimated equations in the Natural Capital Sample (A result already noted by Gylfason and Zoega, 2002). At the same time, the estimated coefficients for other variables remain almost untouched by this specification change and their values remain very close to those reported in Table 2, except for the coefficient for natural capital share, which increases even more in absolute value. ${ }^{12}$ Thus, for a given level of NR dependence, an increase in

\footnotetext{
${ }^{12}$ To save space the results are not reported here.
} 
NR abundance is associated with an increase in economic growth. Surprisingly, this result was not detected in the Primary Exports Sample. If both primary exports share and primary exports per capita are included in all the estimated equations, the estimated coefficients for all variables remain almost the same as those reported in Table 3 and the coefficient for primary exports per capita is still insignificant and close to zero.

Table 6: OLS estimates of the natural resource curse for Natural Capital Sample using several measures of NR dependence/abundance.

Dependent variable is economic growth.

\begin{tabular}{|c|c|c|c|c|c|}
\hline \multicolumn{6}{|c|}{ OLS method; Obs. 74} \\
\hline Constant & $X$ & $\begin{array}{r}\text { Log initial } \\
\text { income }\end{array}$ & $\begin{array}{r}\text { Investment } \\
\text { ratio }\end{array}$ & $\begin{array}{r}\text { Enrollment } \\
\text { rate }\end{array}$ & $\mathrm{R}^{2}$ \\
\hline \multicolumn{6}{|c|}{$X=$ Natural capital share } \\
\hline $9.96(5.37)$ & $-0.07(4.17)$ & $-1.47(6.66)$ & ${ }^{\mathrm{a}} 0.08(2.47)$ & $0.05(5.34)$ & 0.65 \\
\hline${ }^{b} 3.11(1.97)$ & $-0.09(4.27)$ & $-0.53(3.37)$ & $0.17(4.87)$ & & 0.51 \\
\hline $6.92(4.39)$ & $-0.13(6.10)$ & $-0.52(2.85)$ & & & 0.34 \\
\hline $2.50(9.01)$ & $-0.10(5.14)$ & & & & 0.27 \\
\hline \multicolumn{6}{|c|}{$X=$ Natural capital per capita } \\
\hline $7.12(3.66)$ & ${ }^{\mathrm{c}} 0.00(0.00)$ & $-1.35(5.40)$ & $0.12(3.46)$ & $0.05(5.38)$ & 0.57 \\
\hline${ }^{\mathrm{c}}-1.10(0.77)$ & ${ }^{\mathrm{c}} 0.01(0.49)$ & ${ }^{\mathrm{c}}-0.29(1.61)$ & $0.23(6.56)$ & & 0.38 \\
\hline${ }^{\mathrm{c}} 1.77(1.03)$ & ${ }^{\mathrm{c}} 0.01(0.57)$ & ${ }^{\mathrm{c}}-0.06(0.27)$ & & & 0.00 \\
\hline $1.31(4.63)$ & ${ }^{\mathrm{c}} 0.01(0.51)$ & & & & 0.00 \\
\hline \multicolumn{6}{|c|}{$X=$ Primary exports share } \\
\hline $6.75(3.71)$ & $-0.05(2.97)$ & $-1.19(5.00)$ & $0.13(3.82)$ & $0.04(4.29)$ & 0.62 \\
\hline${ }^{\mathrm{c}} 0.63(0.50)$ & $-0.07(4.33)$ & a $-0.33(2.30)$ & $0.21(6.50)$ & & 0.51 \\
\hline a $3.55(2.38)$ & $-0.09(4.44)$ & ${ }^{\mathrm{c}}-0.14(0.76)$ & & & 0.22 \\
\hline $2.44(8.14)$ & $-0.09(4.39)$ & & & & 0.21 \\
\hline \multicolumn{6}{|c|}{$X=$ Primary exports per capita } \\
\hline $6.67(3.45)$ & ${ }^{\mathrm{c}}-0.02(1.37)$ & $-1.28(5.18)$ & $0.12(3.28)$ & $0.06(5.63)$ & 0.58 \\
\hline${ }^{\mathrm{c}}-0.97(0.59)$ & ${ }^{\mathrm{c}} 0.01(0.39)$ & ${ }^{\mathrm{c}}-0.31(1.45)$ & $0.23(6.55)$ & & 0.38 \\
\hline${ }^{\mathrm{c}} 2.14(1.07)$ & ${ }^{\mathrm{c}} 0.01(0.61)$ & ${ }^{\mathrm{c}}-0.11(0.40)$ & & & 0.01 \\
\hline $1.34(5.30)$ & ${ }^{\mathrm{c}} 0.01(0.47)$ & & & & 0.00 \\
\hline
\end{tabular}

Notes: Only those country observations are used for which all three measures of natural-resource abundance are available. As a result, 74 out of the total 86 observations are employed. Absolute values of $\mathrm{t}$-statistics are in parenthesis. All the estimated coefficients are significant at the $1 \%$ significance level.

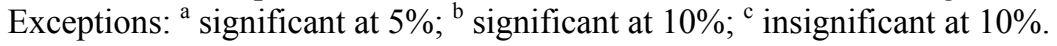


Table 7: OLS estimates of the natural resource curse for Primary Exports Sample using several measures of NR dependence/abundance.

Dependent variable is economic growth.

\begin{tabular}{|c|c|c|c|c|c|}
\hline \multicolumn{6}{|c|}{ OLS method; Obs. 74} \\
\hline \multirow[b]{2}{*}{ Constant } & \multirow[b]{2}{*}{$X$} & \multirow{2}{*}{$\begin{array}{l}\text { Log initial } \\
\text { income }\end{array}$} & \multicolumn{2}{|c|}{ Log investment } & \multirow[b]{2}{*}{$\mathrm{R}^{2}$} \\
\hline & & & Openness & ratio & \\
\hline \multicolumn{6}{|c|}{$\mathrm{X}=$ Primary exports share } \\
\hline $8.77(6.88)$ & $-0.06(5.09)$ & $-1.29(7.62)$ & $2.36(6.60)$ & \multirow[t]{4}{*}{$1.13(5.10)$} & 0.68 \\
\hline $8.88(5.98)$ & $-0.06(3.94)$ & $-0.98(5.33)$ & $2.99(7.64)$ & & 0.56 \\
\hline $\mathrm{b}_{3} .06(1.78)$ & $-0.08(4.07)$ & ${ }^{\mathrm{c}}-0.12(0.62)$ & & & 0.19 \\
\hline $2.01(7.17)$ & $-0.08(4.06)$ & & & & 0.19 \\
\hline \multicolumn{6}{|c|}{$X=$ Primary exports per capita } \\
\hline $6.71(3.99)$ & ${ }^{\mathrm{c}}-0.01(0.73)$ & $-1.11(4.93)$ & $2.77(6.75)$ & \multirow[t]{4}{*}{$1.02(3.97)$} & 0.56 \\
\hline $7.12(3.86)$ & ${ }^{\mathrm{c}}-0.01(0.47)$ & $-0.86(3.62)$ & $3.30(7.74)$ & & 0.46 \\
\hline${ }^{\mathrm{c}} 0.75(0.33)$ & ${ }^{\mathrm{c}} 0.01(0.25)$ & ${ }^{\mathrm{c}} 0.04(0.14)$ & & & 0.00 \\
\hline $1.06(4.54)$ & ${ }^{\mathrm{c}} 0.01(0.46)$ & & & & 0.00 \\
\hline \multicolumn{6}{|c|}{$X=$ Natural capital share } \\
\hline $9.25(6.14)$ & $-0.05(3.04)$ & $-1.27(6.78)$ & $2.52(6.44)$ & \multirow[t]{4}{*}{$0.77(3.04)$} & 0.61 \\
\hline $10.0(6.36)$ & $-0.07(3.95)$ & $-1.11(5.84)$ & $2.83(7.05)$ & & 0.56 \\
\hline $5.59(2.98)$ & $-0.10(4.80)$ & ${ }^{b}-0.41(1.93)$ & & & 0.25 \\
\hline $2.00(7.51)$ & $-0.08(4.33)$ & & & & 0.21 \\
\hline \multicolumn{6}{|c|}{$X=$ Natural capital per capita } \\
\hline $7.83(4.79)$ & ${ }^{\mathrm{c}} 0.01(0.68)$ & $-1.26(5.68)$ & $2.79(6.73)$ & \multirow[t]{4}{*}{$0.99(3.84)$} & 0.56 \\
\hline $8.37(4.70)$ & ${ }^{c} 0.02(1.01)$ & $-1.04(4.44)$ & $3.34(7.84)$ & & 0.47 \\
\hline${ }^{\mathrm{c}} 0.31(0.16)$ & ${ }^{\mathrm{c}}-0.00(0.10)$ & ${ }^{\mathrm{c}} 0.10(0.40)$ & & & 0.00 \\
\hline $1.10(4.19)$ & ${ }^{\mathrm{c}} 0.00(0.13)$ & & & & 0.00 \\
\hline
\end{tabular}

Notes: Only those country observations are used for which all three measures of natural-resource abundance are available. As a result, 74 out of the total 86 observations are employed. Absolute values of t-statistics are in parenthesis. All the estimated coefficients are significant at the $1 \%$ significance level. Exceptions: ${ }^{\mathrm{a}}$ significant at $5 \% ;{ }^{\mathrm{b}}$ significant at $10 \%{ }^{\mathrm{c}}$ insignificant at $10 \%$.

To summarize, we have so far shown that in the cross-country growth regressions, natural resources themselves do not prove to be a threat to economic growth. Only NR dependence is associated with slow growth. Additionally, the correlation between the measures of NR abundance and dependence is very low in both data samples. It is the structure of the economy, namely the relatively small size of the non-resource sector, that results in increased NR dependence and is associated with slow economic growth. Therefore, it seems that cross-country growth regressions were previously misinterpreted when used as evidence for the curse of natural resources. Instead, NR dependence, indeed, serves as a proxy for a more fundamental structural problem that causes slow economic growth. 


\subsection{The Link between NR Effects and Institutional Development}

Many authors, including Auty, Gelb, Gylfason, and Sachs and Warner, stress the role of policies and institutions in the curse of natural resources. Robinson, et al. (2002) and Mehlum, et al. (2002) develop models combining political incentives with NR endowments to generate the curse result. Mehlum even shows statistical evidence of the interaction between institutions and NR dependence in cross-country growth regressions. As seen above, when we include various democracy indicators to measure the effect of the institutional environment, the negative relationship between NR dependence and economic growth remains unchanged. To further address the supposed interaction between institutions and NR dependence, we sort the countries in each sample into quartiles using the democracy indicators, and estimate the basic regressions of economic growth on the log initial income and the appropriate measure of NR dependence.

In Figure 2, we plot the index of civil liberties against natural capital share in the Natural Capital Sample, and against primary exports share in the Primary Exports Sample. ${ }^{13}$ It shows a relatively homogeneous distribution of natural capital dependence in both samples for different levels of civil liberties, with one exception. All eight of the most NR dependent countries in the Natural Capital Sample and four out of the six most NR dependent countries in the Primary Exports Sample have a very low level of civil liberties. Therefore, when we sort the countries according to quartiles, almost all the extremely NR dependent countries fall in the first quartile. This might bias down the coefficient estimate for NR dependence in this quartile, particularly if non-linearity in the relationship between economic growth and NR dependence is present. Indeed, when regressing economic growth on log initial income, natural capital share, and natural capital share squared in the Natural Capital Sample, the coefficient for natural capital share squared is significant at the 10 per cent level. Once the eight extremely NR dependent countries are excluded from the sample, the coefficient becomes insignificant. With the Primary Exports Sample, the coefficient for primary exports share squared is insignificant. Once the six extremely NR dependent countries are excluded, however, the t-statistic drops from 1.38 to 0.18 . This result indicates the

\footnotetext{
${ }^{13}$ To save space only the index of civil liberties is chosen as an example; the distribution would be very similar if the indices of political rights, democracy, or autocracy were selected.
} 
presence of a non-linearity that disappears when the most NR dependent countries are excluded. In further analysis, therefore, we also employ reduced samples with the eight (for the Natural Capital Sample) and six (for the Primary Exports Sample) extremely NR dependent countries excluded.

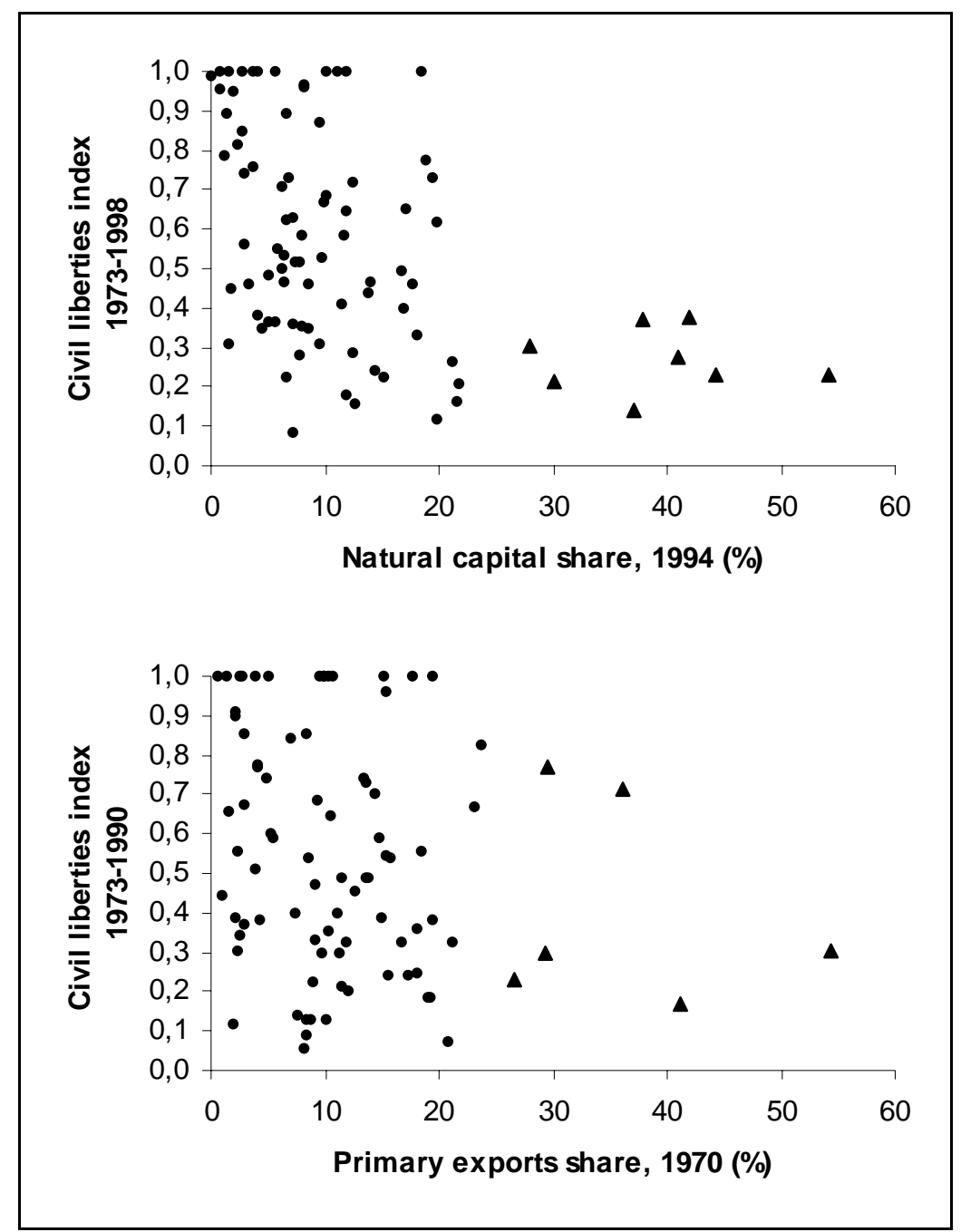

Figure 2: NR dependence and the index of civil liberties in the Natural Capital Sample and Primary Exports Sample.

Note: Triangles represent the most NR dependent countries, which are the Central African Republic, Chad, Guinea-Bissau, Madagascar, Mali, Niger, Sierra Leone, and Zambia in the Natural Capital Sample and the Ivory Coast, Gambia, Mauritania, Mauritius, Uganda, and Zambia in the Primary Exports Sample. 
Figures 3 and 4 plot the estimated coefficients for natural capital share (Natural Capital Sample) and primary exports share (Primary Exports Sample) in groups of countries sorted with respect to the civil liberties and autocracy indices. ${ }^{14}$ The estimated coefficients are plotted as a function of the average value of the appropriate index in each group.
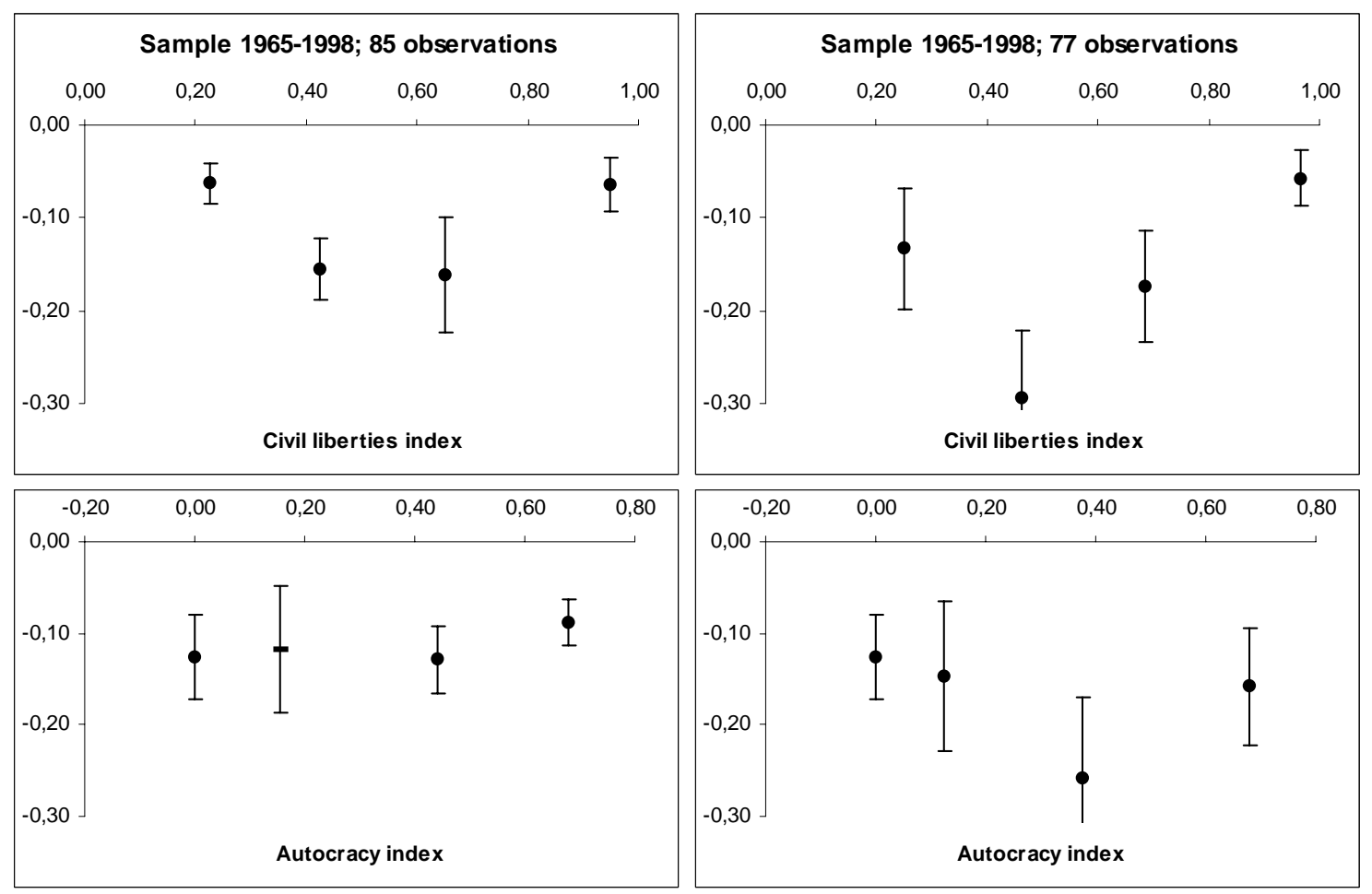

Figure 3: The resource curse estimated coefficient as a function of democracy measures in the Natural Capital Sample. The graphs on the left show results for the full sample; on the right, results for a reduced sample with the eight most NR dependent countries excluded.

Notes: On the horizontal axis we plot the estimated coefficient of natural capital share in the regression of economic growth on a constant, natural capital share, and log initial income. The error bars stand for estimated standard errors. Coefficients that are insignificant at the 10 per cent level are plotted with a dash. The four groups contain 21 (19), 23 (20), 20 (19), and 21 (19) country observations, when sorting with respect to the index of civil liberties and 25 (25), 18 (14), 21 (19), and 21 (19) country observations, when sorting with respect to the autocracy index. The figures in parentheses give the number of country observations when the reduced sample excluding the eight most NR dependent countries is employed.

\footnotetext{
${ }^{14}$ The results with the indices of democracy and political rights would be very close to those with the index of civil liberties.
} 


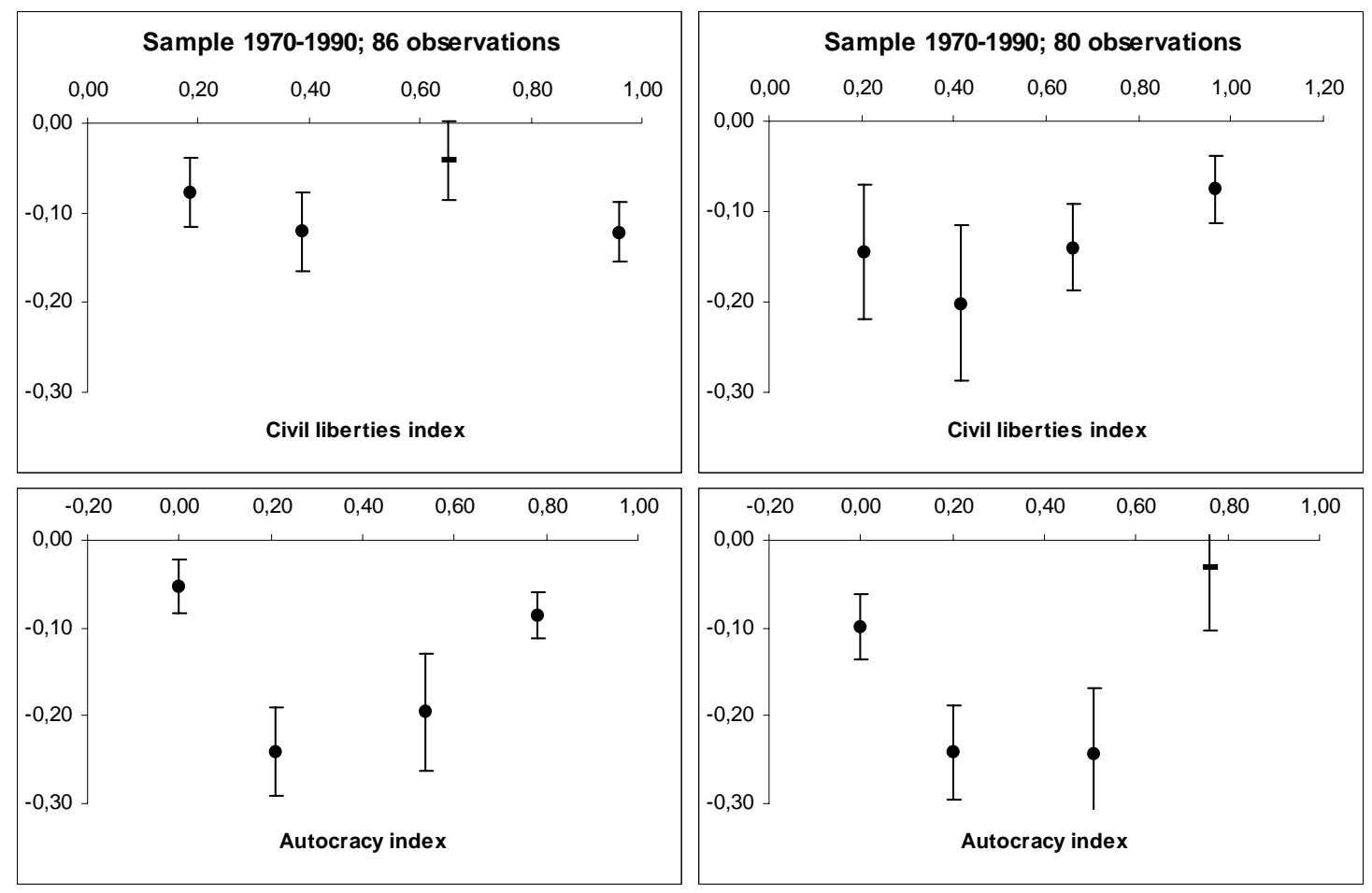

Figure 4: The resource curse estimated coefficient as a function of democracy measures in the Primary Exports Sample. The graphs on the left show results for the full sample; on the right, results for a reduced sample with the six most NR dependent countries excluded.

Notes: On the horizontal axis we plot the estimated coefficient of primary exports share in the regression of economic growth on a constant, primary exports share, and log initial income. The error bars stand for estimated standard errors. Coefficients that are insignificant at the 10 per cent level are plotted with a dash. The four groups contain 21 (22), 22 (18), 22 (20), and 21 (20) country observations, when sorting with respect to the index of civil liberties and 28 (26), 15 (14), 23 (20), and 20 (20) country observations, when sorting with respect to the autocracy index. The figures in parentheses give the number of country observations when the reduced sample excluding the six most NR dependent countries is employed.

The largest differences in the value of estimated coefficients for NR dependence are detected for countries sorted by quartiles on the index of civil liberties for the Natural Capital Sample and into the quartiles of the autocracy index for the Primary Exports Sample. These are also the only cases where some of the differences in the values of estimated coefficients are statistically significant. With the Natural Capital Sample, statistically significant differences are detected between the first and second and between the second and fourth quartile at the 5 per cent level. When the eight most NR dependent countries are excluded, statistically significant differences at the 10 per cent level are present between the first and second quartile and between the third and fourth 
quartile, and at the 1 per cent level between the second and third quartile. With the Primary Exports Sample, statistically significant differences are detected between the first and second quartile and between the second and fourth quartile at the 1 percent level, and between the first and third quartile at the 10 per cent level. When the six most NR dependent countries are excluded, statistically significant differences are present between the first and second, second and fourth, and third and fourth quartile at the 5 per cent level, and between the first and third quartile at the 10 per cent.

Figures 3 and 4 show a prevailing U-shape of the coefficient for NR dependence as a function of the civil liberties index with the Natural Capital Sample, and of the autocracy index with the Primary Exports Sample. The U-shape becomes more pronounced once the most NR dependent countries are excluded from both samples. The functions' U-shape suggests that further possible non-linearity in the resource curse regressions should be tested. To explore this issue, we tested for possible non-linear effects in the basic resource curse regressions of economic growth on log initial income, and the appropriate measure of NR dependence. Specifically, we included the indices of civil liberties and autocracy squared and the interaction term of the appropriate measure of NR dependence with the indices of civil liberties and autocracy, defined as NR dependence times the respective index. We also controlled for the linear effects of both indices in the regressions. The results provided limited support for non-linearity. With the Natural Capital Sample, the interaction terms are significant at the 10 per cent level and with the eight most NR dependent countries excluded, even at the 1 per cent level, although only if the linear effects of the indices of civil liberties and autocracy are not considered. The significance of the interaction terms is in line with the observed functions' U-shapes. With the Primary Exports Sample, only the autocracy index squared is significant at the 1 per cent level with the full, and significant at the 5 per cent level with the six most NR dependent countries excluded. Admittedly, this result is somehow confusing, and it is not clear how it is related to the observed U-shapes of the functions in Figure 4.

Gylfason (2001) states, "It needs to be emphasized that it is not the existence of natural resources as such that seems to be the problem, but rather the failure of public authorities to avert the dangers that accompany the gifts of nature." Indeed, the prevailing interpretation suggests that healthy institutions and wise economic policies 
can mitigate the dangers of NR wealth. In this paper, however, we present evidence that it is not natural resources per se, but neglect of the non-resource sector that is the real cause for slow growth. Poor institutions seem to be the underlying cause of both slow growth and the resulting high degree of NR dependence.
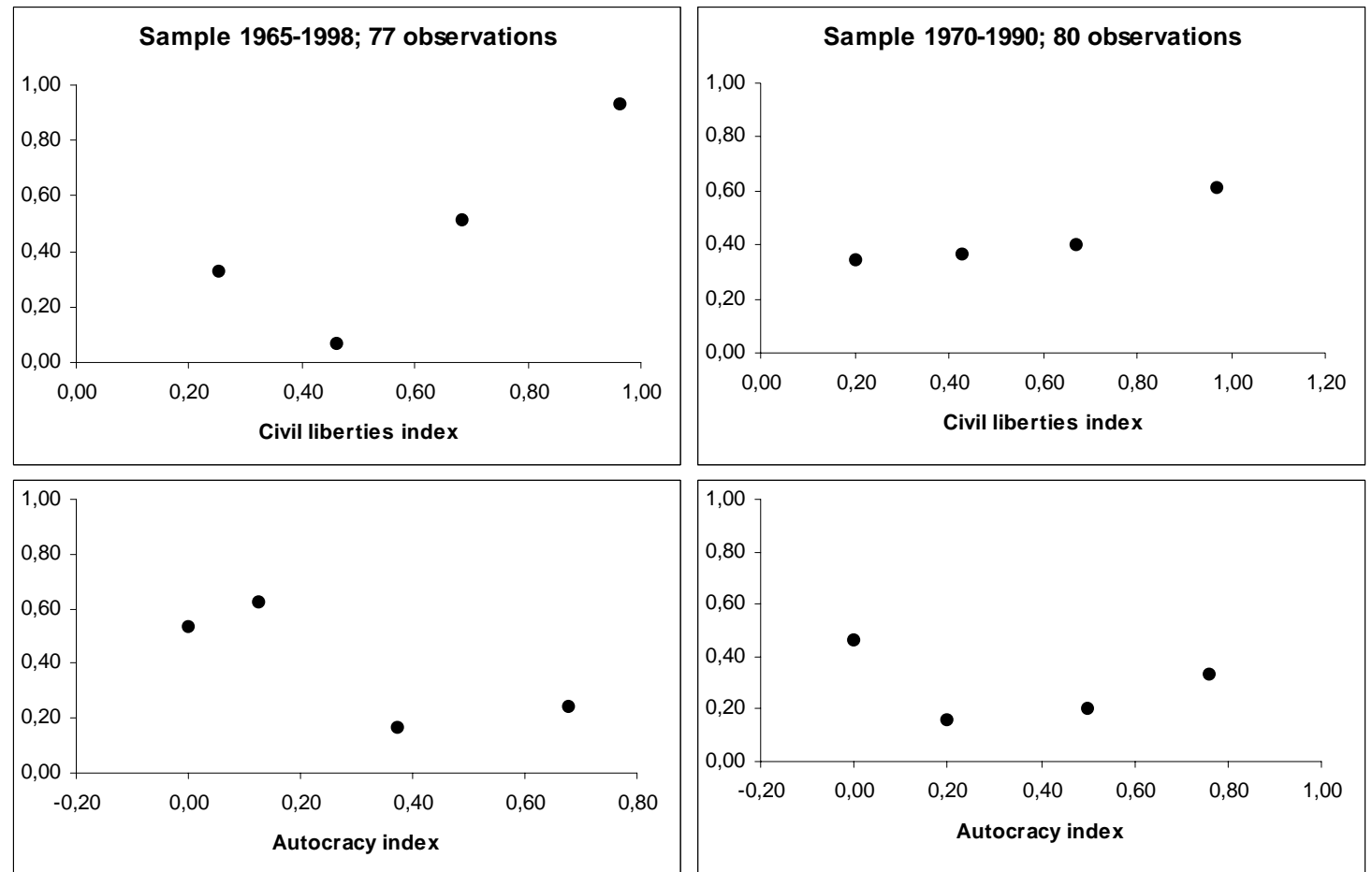

Figure 5: Correlation between natural capital share and natural capital per capita in the Natural Capital Sample and between primary exports share and primary exports per capita in the Primary Exports Sample plotted as a function of democracy measures. The graphs show results for reduced samples of 77 and 80 observations, where the eight most NR dependent countries are excluded from the Natural Capital Sample and the six most NR dependent countries are excluded from the Primary Exports Sample.

In Figure 5, we plot the correlation between NR dependence and abundance measures for the two samples as a function of civil liberties and autocracy indices. Reduced samples with the most NR dependent countries excluded are used, and the correlation coefficient is computed for the same country groups as the coefficient for NR dependence in Figures 3 and 4. Let us focus on the cases where statistically significant differences were detected between the values of the estimated coefficients. 
Remember that these are the cases where the countries are sorted with respect to the civil liberties index in the Natural Capital Sample and with respect to the autocracy index in the Primary Exports Sample. Indeed, the differences in the correlation coefficients are also the greatest here. Moreover, the correlation between the measures of NR dependence and abundance is low where the estimated coefficient for NR dependence was large, and vice-versa. In the remaining cases, the differences in the correlation coefficients are not that distinct. Nevertheless, the overall pattern remains: for groups of countries with a stronger resource curse result, the correlation between the measures of NR dependence and abundance tends to be lower and vice-versa.

The results in Figure 5 suggest that the capacity of NR dependence to measure the neglect of the non-resource sector can differ in different subsets of countries and that it is not NR dependence, but neglect of the non-resource sector that is the real cause of slow growth. If the correlation between NR abundance and dependence is high for a given subset of countries, then NR dependence is largely driven by real resource wealth and cannot serve as a good measure of non-resource sector neglect. Therefore, the curse of natural resources estimated in this subset of countries is not very strong. Conversely, the resource curse result is much stronger in those subsets of countries where the correlation between NR dependence and abundance is low. In such cases NR dependence does not vary with real NR wealth and serves as a good measure of nonresource sector neglect.

The argument presented above can also partly explain the prevailing U-shape of the coefficient for NR dependence plotted as a function of the civil liberties and autocracy indices in Figures 3 and 4. It is quite likely that the variation in economic institutions and policies and consequently in the neglect of the non-resource sector are much higher among countries that are moving toward democracy than among fully democratic or authoritarian countries. In other words, the imaginary mapping from the level of democracy to the quality of economic institutions and policies has the shape of a sigmoid. Additionally, if NR wealth is distributed more or less randomly and homogeneously, then variation in the neglect of the non-resource sector relative to variation in the NR wealth would be much higher in the second and third quartiles than in the first and fourth quartiles, when the countries are sorted with respect to the civil liberties and autocracy indices. Thus, the capacity of NR dependence to measure non- 
resource sector neglect should be much higher in the second and third quartiles, which would result in the observed U-shape of the resource curse coefficient plotted as a function of civil liberties and autocracy indices.

\section{Conclusion}

The results of cross-country growth regressions presented here provide no statistical evidence that natural resources themselves are associated with slow economic growth. Previous cross-country growth regressions re-estimated were misinterpreted when used as evidence for the curse of natural resources. These regressions clearly capture a different statistical relationship between the structure of the economy and economic growth. Countries with small non-resource sectors exhibit both a high degree of NR dependence and slow growth. Misinterpreting the previous results has led researchers and policy makers to focus overly on the resource sector. In fact, the link between measured resource dependence and growth is an artifact arising from factors that cause slow growth and underdeveloped economies in general. Our focus should be these factors that appear to be independent of resource abundance, but may be linked to institutional quality. 


\title{
Appendix A - Data and Definitions
}

\author{
Natural Capital Sample
}

\begin{tabular}{|c|c|c|c|c|c|c|c|c|c|c|}
\hline Country & $\begin{array}{r}\text { Economic } \\
\text { growth }\end{array}$ & $\begin{array}{r}\text { Natural } \\
\text { capital } \\
\text { share }\end{array}$ & $\begin{array}{l}\text { Natural } \\
\text { capitalLc } \\
\text { p. cap. }\end{array}$ & $\begin{array}{l}\text { inititial } \\
\text { income }\end{array}$ & $\begin{array}{c}\text { vestment } 1 \\
\text { ratio }\end{array}$ & $\begin{array}{r}\text { nrollment } \\
\text { rate }\end{array}$ & Autocracy I & Democracy & $\begin{array}{r}\text { Civil } \\
\text { liberties }\end{array}$ & $\begin{array}{r}\text { Political } \\
\text { rights }\end{array}$ \\
\hline Argentina & 0.400 & 6.697 & 12.855 & 9.238 & 22.810 & 56.103 & 0.376 & 0.409 & 0.622 & 0.641 \\
\hline Australia & 1.700 & 11.889 & 44.419 & 9.433 & 23.727 & 85.758 & 0.000 & 1.000 & 1.000 & 1.000 \\
\hline Austria & 2.600 & 2.642 & 7.898 & 9.202 & 23.788 & 92.031 & 0.000 & 1.000 & 1.000 & 1.000 \\
\hline Bangladesh & 1.400 & 14.060 & 4.087 & 6.790 & 20.000 & 17.714 & 0.348 & 0.244 & 0.468 & 0.519 \\
\hline Belgium & 2.300 & 0.003 & 2.241 & 9.320 & 19.545 & 96.871 & 0.000 & 1.000 & 0.987 & 1.000 \\
\hline Benin & 0.100 & 7.678 & 2.386 & 6.720 & 15.176 & 12.000 & 0.506 & 0.152 & 0.282 & 0.231 \\
\hline Botswana & 7.700 & 6.302 & 6.764 & 6.217 & 26.853 & 25.688 & 0.000 & 0.870 & 0.705 & 0.853 \\
\hline Brazil & 2.200 & 7.894 & 9.058 & 8.055 & 20.690 & 33.097 & 0.424 & 0.385 & 0.583 & 0.654 \\
\hline Burkina Faso & 0.900 & 16.911 & 3.046 & 6.468 & 21.000 & 3.448 & 0.542 & 0.036 & 0.397 & 0.276 \\
\hline Burundi & 0.900 & 19.858 & 2.545 & 6.034 & 11.500 & 3.300 & 0.669 & 0.003 & 0.115 & 0.032 \\
\hline Cameroon & 1.300 & 21.077 & 8.609 & 6.814 & 21.458 & 17.467 & 0.712 & 0.021 & 0.263 & 0.141 \\
\hline $\begin{array}{l}\text { Canada } \\
\text { Central } \\
\text { African }\end{array}$ & 1.800 & 11.069 & 39.237 & 9.446 & 21.545 & 86.900 & 0.000 & 1.000 & 1.000 & 1.000 \\
\hline Republic & -1.200 & 30.160 & 7.344 & 7.400 & 10.409 & 9.556 & 0.571 & 0.106 & 0.212 & 0.167 \\
\hline Chad & -0.600 & 37.133 & 7.159 & 6.936 & 7.471 & 4.923 & 0.685 & 0.012 & 0.141 & 0.096 \\
\hline Chile & 1.900 & 9.782 & 17.575 & 8.428 & 19.000 & 54.806 & 0.303 & 0.382 & 0.526 & 0.391 \\
\hline China & 6.800 & 7.229 & 3.507 & 5.852 & 30.619 & 44.500 & 0.741 & 0.000 & 0.083 & 0.077 \\
\hline Colombia & 2.000 & 7.183 & 7.687 & 8.023 & 18.971 & 39.516 & 0.000 & 0.774 & 0.628 & 0.776 \\
\hline Congo & 1.400 & 14.466 & 5.828 & 6.282 & 31.720 & 50.065 & 0.639 & 0.091 & 0.244 & 0.173 \\
\hline Costa Rica & 1.200 & 8.205 & 9.822 & 8.274 & 20.618 & 40.242 & 0.000 & 1.000 & 0.968 & 1.000 \\
\hline Ivory Coast & -0.800 & 18.009 & 4.984 & 7.568 & 17.324 & 16.424 & 0.832 & 0.000 & 0.333 & 0.186 \\
\hline $\begin{array}{l}\text { Denmark } \\
\text { Dominican }\end{array}$ & 1.900 & 3.753 & 12.051 & 9.459 & 22.939 & 101.419 & 0.000 & 1.000 & 1.000 & 1.000 \\
\hline Republic & 2.300 & 12.407 & 10.679 & 7.625 & 20.794 & 35.333 & 0.145 & 0.430 & 0.718 & 0.776 \\
\hline Ecuador & 1.800 & 17.011 & 11.497 & 7.419 & 19.235 & 43.448 & 0.150 & 0.582 & 0.654 & 0.628 \\
\hline Egypt & 3.500 & 4.550 & 3.019 & 6.919 & 20.765 & 52.455 & 0.553 & 0.026 & 0.346 & 0.288 \\
\hline El Salvador & -0.400 & 2.846 & 1.516 & 8.428 & 15.500 & 24.419 & 0.166 & 0.445 & 0.564 & 0.641 \\
\hline Finland & 2.400 & 6.602 & 17.812 & 9.152 & 23.970 & 101.938 & 0.000 & 1.000 & 0.891 & 0.904 \\
\hline France & 2.100 & 2.735 & 9.783 & 9.277 & 21.758 & 86.031 & 0.012 & 0.815 & 0.846 & 1.000 \\
\hline Gambia & 0.400 & 11.844 & 2.729 & 7.132 & 19.500 & 13.097 & 0.088 & 0.656 & 0.647 & 0.660 \\
\hline Ghana & -0.800 & 7.221 & 2.518 & 7.724 & 11.875 & 31.333 & 0.500 & 0.117 & 0.359 & 0.250 \\
\hline Greece & 2.400 & 3.657 & 6.790 & 8.764 & 25.394 & 80.125 & 0.167 & 0.703 & 0.756 & 0.859 \\
\hline $\begin{array}{l}\text { Guatemala } \\
\text { Guinea- }\end{array}$ & 0.700 & 3.309 & 2.070 & 7.923 & 14.324 & 16.379 & 0.252 & 0.291 & 0.462 & 0.538 \\
\hline Bissau & -0.100 & 44.204 & 10.508 & 6.384 & 29.150 & 6.417 & 0.592 & 0.083 & 0.229 & 0.243 \\
\hline Haiti & -0.800 & 6.683 & 1.108 & 7.494 & 10.875 & 13.300 & 0.716 & 0.131 & 0.224 & 0.141 \\
\hline Honduras & 0.600 & 9.940 & 4.153 & 7.560 & 19.765 & 22.083 & 0.091 & 0.353 & 0.667 & 0.571 \\
\hline India & 2.700 & 19.788 & 5.010 & 6.751 & 18.559 & 33.969 & 0.000 & 0.835 & 0.615 & 0.782 \\
\hline Indonesia & 4.700 & 12.378 & 9.730 & 6.270 & 25.500 & 31.469 & 0.685 & 0.000 & 0.288 & 0.250 \\
\hline Ireland & 3.000 & 8.117 & 23.284 & 8.822 & 21.030 & 89.875 & 0.000 & 1.000 & 0.962 & 1.000 \\
\hline Italy & 2.500 & 1.320 & 4.179 & 9.107 & 21.606 & 72.313 & 0.000 & 1.000 & 0.891 & 0.974 \\
\hline Jamaica & -0.400 & 6.776 & 4.061 & 8.247 & 24.853 & 58.296 & 0.000 & 0.982 & 0.731 & 0.865 \\
\hline
\end{tabular}




\begin{tabular}{|c|c|c|c|c|c|c|c|c|c|c|}
\hline Japan & 3.500 & 0.758 & 2.386 & 8.933 & 30.818 & 92.387 & 0.000 & 1.000 & 0.955 & 0.936 \\
\hline Jordan & -0.400 & 1.589 & 1.213 & 8.001 & 29.391 & 47.970 & 0.791 & 0.050 & 0.308 & 0.301 \\
\hline Kenya & 1.300 & 9.439 & 2.123 & 6.445 & 17.382 & 17.097 & 0.591 & 0.053 & 0.308 & 0.250 \\
\hline Korea & 6.600 & 1.750 & 3.362 & 7.385 & 29.353 & 71.625 & 0.364 & 0.321 & 0.449 & 0.558 \\
\hline Madagascar & -1.800 & 41.871 & 8.557 & 7.207 & 10.500 & 14.833 & 0.391 & 0.233 & 0.378 & 0.423 \\
\hline Malawi & 0.500 & 11.782 & 1.108 & 6.147 & 17.385 & 5.871 & 0.765 & 0.103 & 0.179 & 0.212 \\
\hline Malaysia & 4.100 & 8.618 & 14.477 & 7.623 & 28.412 & 47.939 & 0.094 & 0.535 & 0.462 & 0.590 \\
\hline Mali & -0.100 & 41.041 & 6.289 & 6.545 & 17.500 & 7.121 & 0.552 & 0.142 & 0.276 & 0.212 \\
\hline Mauritania & -0.100 & 21.570 & 6.658 & 7.346 & 20.357 & 9.226 & 0.676 & 0.000 & 0.160 & 0.090 \\
\hline Mauritius & 3.800 & 1.245 & 1.622 & 7.786 & 21.824 & 44.813 & 0.000 & 0.955 & 0.788 & 0.853 \\
\hline Mexico & 1.500 & 5.885 & 8.596 & 8.425 & 19.588 & 43.032 & 0.376 & 0.138 & 0.551 & 0.545 \\
\hline Morocco & 1.800 & 4.075 & 2.901 & 7.478 & 20.441 & 25.875 & 0.812 & 0.000 & 0.385 & 0.429 \\
\hline Mozambique & 0.500 & 12.681 & 1.490 & 6.442 & 12.737 & 5.000 & 0.588 & 0.125 & 0.159 & 0.196 \\
\hline Namibia & 0.700 & 10.071 & 8.965 & 8.341 & 19.053 & 51.667 & 0.000 & 0.600 & 0.685 & 0.796 \\
\hline Nepal & 1.100 & 17.698 & 3.547 & 6.713 & 17.500 & 21.500 & 0.529 & 0.185 & 0.462 & 0.519 \\
\hline Netherlands & 1.900 & 1.524 & 5.155 & 9.392 & 21.848 & 99.375 & 0.000 & 1.000 & 1.000 & 1.000 \\
\hline New Zealand & 0.700 & 18.473 & 54.241 & 9.455 & 22.242 & 86.515 & 0.000 & 1.000 & 1.000 & 1.000 \\
\hline Nicaragua & -3.300 & 13.878 & 4.746 & 8.655 & 19.971 & 33.515 & 0.434 & 0.213 & 0.436 & 0.397 \\
\hline Niger & -2.500 & 54.241 & 15.874 & 7.427 & 11.421 & 4.094 & 0.606 & 0.097 & 0.231 & 0.122 \\
\hline Norway & 3.000 & 10.016 & 33.106 & 9.198 & 26.697 & 93.813 & 0.000 & 1.000 & 1.000 & 1.000 \\
\hline Pakistan & 2.700 & 5.552 & 2.347 & 6.531 & 16.265 & 15.630 & 0.253 & 0.433 & 0.365 & 0.410 \\
\hline $\begin{array}{l}\text { Panama } \\
\text { Papua New }\end{array}$ & 0.700 & 6.473 & 7.212 & 8.272 & 19.579 & 54.903 & 0.415 & 0.294 & 0.468 & 0.359 \\
\hline Guinea & 0.500 & 19.324 & 9.849 & 7.534 & 23.382 & 10.903 & 0.000 & 1.000 & 0.732 & 0.826 \\
\hline Paraguay & 2.300 & 11.539 & 9.084 & 7.619 & 20.765 & 26.469 & 0.579 & 0.168 & 0.410 & 0.410 \\
\hline Peru & -0.300 & 7.784 & 6.039 & 8.437 & 20.971 & 52.750 & 0.281 & 0.388 & 0.519 & 0.500 \\
\hline Philippines & 0.900 & 6.174 & 3.560 & 7.927 & 21.647 & 61.667 & 0.376 & 0.400 & 0.500 & 0.538 \\
\hline Portugal & 3.200 & 2.313 & 5.076 & 8.547 & 27.000 & 59.000 & 0.253 & 0.700 & 0.814 & 0.859 \\
\hline Rwanda & 0.000 & 21.708 & 1.371 & 6.477 & 12.647 & 4.519 & 0.661 & 0.024 & 0.205 & 0.103 \\
\hline Senegal & -0.400 & 16.785 & 6.711 & 7.300 & 12.441 & 12.333 & 0.450 & 0.124 & 0.494 & 0.462 \\
\hline Sierra Leone & -1.600 & 28.009 & 4.008 & 6.630 & 7.357 & 13.154 & 0.566 & 0.081 & 0.301 & 0.237 \\
\hline South Africa & 0.100 & 5.043 & 5.432 & 8.991 & 22.206 & 62.231 & 0.247 & 0.731 & 0.365 & 0.468 \\
\hline Spain & 2.300 & 2.857 & 7.054 & 8.927 & 23.000 & 84.000 & 0.226 & 0.665 & 0.744 & 0.840 \\
\hline Sri Lanka & 3.000 & 7.421 & 4.259 & 7.012 & 22.103 & 57.032 & 0.047 & 0.662 & 0.519 & 0.692 \\
\hline Sweden & 1.400 & 5.608 & 16.204 & 9.437 & 19.939 & 90.906 & 0.000 & 1.000 & 1.000 & 0.994 \\
\hline Switzerland & 1.200 & 0.868 & 3.204 & 9.805 & 25.182 & 85.387 & 0.000 & 1.000 & 1.000 & 1.000 \\
\hline Thailand & 5.000 & 6.486 & 8.728 & 7.007 & 28.706 & 29.182 & 0.203 & 0.394 & 0.532 & 0.545 \\
\hline $\begin{array}{l}\text { Togo } \\
\text { Trinidad and }\end{array}$ & -0.600 & 15.184 & 3.296 & 7.408 & 17.316 & 19.813 & 0.619 & 0.019 & 0.224 & 0.083 \\
\hline Tobago & 2.600 & 9.487 & 15.835 & 8.036 & 21.265 & 62.333 & 0.000 & 0.850 & 0.872 & 0.936 \\
\hline Tunisia & 2.700 & 7.908 & 8.385 & 7.671 & 26.147 & 34.121 & 0.721 & 0.018 & 0.353 & 0.224 \\
\hline $\begin{array}{l}\text { Turkey } \\
\text { United }\end{array}$ & 2.100 & 5.019 & 5.142 & 8.108 & 18.613 & 36.750 & 0.103 & 0.738 & 0.481 & 0.660 \\
\hline Kingdom & 1.900 & 1.859 & 5.577 & 9.298 & 17.970 & 87.656 & 0.000 & 1.000 & 0.949 & 1.000 \\
\hline United States & 1.600 & 4.112 & 19.909 & 9.759 & 18.273 & 90.600 & 0.000 & 1.000 & 1.000 & 1.000 \\
\hline Uruguay & 1.200 & 11.645 & 19.513 & 8.659 & 14.441 & 66.742 & 0.278 & 0.575 & 0.583 & 0.609 \\
\hline Venezuela & -0.800 & 18.929 & 25.776 & 8.914 & 21.941 & 32.871 & 0.012 & 0.859 & 0.776 & 0.910 \\
\hline Zambia & -2.000 & 37.770 & 7.199 & 7.186 & 17.828 & 17.133 & 0.574 & 0.185 & 0.372 & 0.391 \\
\hline Zimbabwe & 0.500 & 8.483 & 2.953 & 7.655 & 17.029 & 25.697 & 0.393 & 0.332 & 0.346 & 0.346 \\
\hline
\end{tabular}




\section{Definitions:}

- Economic growth: The average annual growth of real per capita GDP over the period 1965-1998; unit: percent; source: World Bank (2000).

Note: Data are available in Gylfason and Zoega (2002).

- Natural capital share: The share of natural capital in total capital (natural, human, and physical capital) in 1994; the value of natural capital comprises the value of pastureland, cropland, timber resources, non-timber forest resources, protected areas, and subsoil assets; unit: percent; source: World Bank (1997).

Note: Data are available in Gylfason and Zoega (2002).

- Natural capital per capita: The per capita value of pastureland, cropland, timber resources, non-timber forest resources, and subsoil assets in 1994 multiplied by an appropriate constant so that the sample maximum of Natural capital per capita equals the sample maximum of Natural capital share; unit: 1994 U.S. dollars (times 758.5); source: World Bank (1997).

- Log initial income: Natural logarithm of 1965 per capita GNP computed from the 1998 purchasing power parity adjusted per capita GNP by dividing with $(1+\text { Economic growth/100) })^{33}$ and by taking the natural logarithm; unit: index; source: World Bank (2000).

Note: Data are available in Gylfason and Zoega (2002).

- Investment ratio: The average gross domestic investment as a percentage of GDP over the period 1965-1998; unit: percent; source: World Bank (2000).

Note: Data are available in Gylfason and Zoega (2002).

- Enrollment rate: The average secondary school enrollment rate (gross) over the period 1965-1998; unit: percent; source: World Bank (2000).

Note: Data are available in Gylfason and Zoega (2002).

- Autocracy: Average of the Polity IV variable AUTOC over the period 1965-1998 (for each country only the years with available data were used) rescaled to the range 0 to $1 ; 1$ indicates the highest and 0 the lowest level of autocracy; unit: index; source Polity IV Project (2001).

- Democracy: Average of the Polity IV variable DEMOC over the period 1965-1998 (for each country only the years with available data were used) rescaled to the range 0 to $1 ; 1$ indicates the highest and 0 the lowest level of democracy; unit: index; source Polity IV Project (2001).

- Civil liberties: Average of the Freedom House index of civil liberties over the period 1973-1998 (for each country only the years with available data were used) rescaled to the range 0 to $1 ; 1$ indicates the highest and 0 the lowest level of civil liberties; unit: index; source Freedom House (2002).

- Political rights: Average of the Freedom House index of political rights over the period 1973-1998 (for each country only the years with available data were used) rescaled to the range 0 to $1 ; 1$ indicates the highest and 0 the lowest level of political rights; unit: index; source Freedom House (2002). 
Table A.1: Statistics on variables used in the Natural Capital Sample.

\begin{tabular}{|c|c|c|c|c|c|c|}
\hline Variable & Mean & Median & Max. & Min. & $\begin{array}{r}\text { Standard } \\
\text { deviation }\end{array}$ & Obs. \\
\hline Economic growth & 1.36 & 1.30 & 7.70 & -3.30 & 1.92 & 85 \\
\hline Nat. capital share & 11.8 & 8.21 & 54.2 & 0.00 & 10.8 & 85 \\
\hline Nat. capital p. cap. & 8.82 & 6.29 & 54.2 & 1.11 & 9.35 & 85 \\
\hline Log initial income & 7.85 & 7.67 & 9.81 & 5.85 & 1.06 & 85 \\
\hline Invest. ratio & 20.2 & 20.6 & 31.7 & 7.36 & 5.27 & 85 \\
\hline Enrollment rate & 43.8 & 36.8 & 101.9 & 3.30 & 30.2 & 85 \\
\hline Autocracy & 0.31 & 0.28 & 0.83 & 0.00 & 0.28 & 85 \\
\hline Democracy & 0.47 & 0.39 & 1.00 & 0.00 & 0.38 & 85 \\
\hline Civil liberties & 0.56 & 0.52 & 1.00 & 0.08 & 0.28 & 85 \\
\hline Political rights & 0.57 & 0.54 & 1.00 & 0.03 & 0.32 & 85 \\
\hline
\end{tabular}

Table A.2: Correlations of variables used in the Natural Capital Sample.

\begin{tabular}{|c|c|c|c|c|c|}
\hline Variable & $\begin{array}{r}\text { Economic } \\
\text { growth }\end{array}$ & $\begin{array}{r}\text { Nat. capital } \\
\text { share }\end{array}$ & $\begin{array}{l}\text { Nat. capital } \\
\text { p. cap. }\end{array}$ & $\begin{array}{r}\text { Log initial } \\
\text { income }\end{array}$ & $\begin{array}{r}\text { Invest. } \\
\text { ratio }\end{array}$ \\
\hline Economic growth & 1.00 & & & & \\
\hline Nat. capital share & -0.53 & 1.00 & & & \\
\hline Nat. capital p. cap. & 0.05 & 0.12 & 1.00 & & \\
\hline Log initial income & -0.02 & -0.45 & 0.47 & 1.00 & \\
\hline Invest. ratio & 0.61 & -0.41 & 0.16 & 0.21 & 1.00 \\
\hline Enrollment rate & 0.39 & -0.57 & 0.43 & 0.82 & 0.48 \\
\hline Autocracy & -0.32 & 0.41 & -0.32 & -0.65 & -0.28 \\
\hline Democracy & 0.31 & -0.43 & 0.43 & 0.73 & 0.33 \\
\hline Civil liberties & 0.29 & -0.47 & 0.48 & 0.81 & 0.35 \\
\hline Political rights & 0.35 & -0.48 & 0.43 & 0.76 & 0.37 \\
\hline & $\begin{array}{r}\text { Enrollment } \\
\text { rate }\end{array}$ & Autocracy & Democracy & $\begin{array}{r}\text { Civil } \\
\text { liberties }\end{array}$ & $\begin{array}{r}\text { Political } \\
\text { rights }\end{array}$ \\
\hline $\begin{array}{l}\text { Economic growth } \\
\text { Nat. capital share } \\
\text { Nat. capital p. cap. } \\
\text { Log initial income } \\
\text { Invest. ratio }\end{array}$ & & & & & \\
\hline Enrollment rate & 1.00 & & & & \\
\hline Autocracy & -0.66 & 1.00 & & & \\
\hline Democracy & 0.76 & -0.94 & 1.00 & & \\
\hline Civil liberties & 0.81 & -0.88 & 0.92 & 1.00 & \\
\hline Political rights & 0.78 & -0.92 & 0.95 & 0.97 & 1.00 \\
\hline
\end{tabular}




\section{Primary Exports Sample}

\begin{tabular}{|c|c|c|c|c|c|c|c|c|c|c|}
\hline Country & $\begin{array}{r}\text { Economic } \\
\text { growth } \\
\end{array}$ & $\begin{array}{r}\text { Primary } \\
\text { exports } \\
\text { share } \\
\end{array}$ & $\begin{array}{r}\text { Primary } \\
\text { exports } \\
\text { p. cap. }\end{array}$ & $\begin{array}{r}\text { Log initial } \\
\text { income }\end{array}$ & Openness & $\begin{array}{r}\log \\
\text { investment } \\
\text { ratio } \\
\end{array}$ & Autocracy D & Democracy & $\begin{array}{r}\text { Civil } \\
\text { liberties }\end{array}$ & $\begin{array}{r}\text { Political } \\
\text { rights } \\
\end{array}$ \\
\hline Algeria & 1.478 & 19.237 & 5.205 & 8.255 & 0.000 & 3.301 & 0.843 & 0.010 & 0.185 & 0.167 \\
\hline Argentina & -0.688 & 5.262 & 7.619 & 9.088 & 0.000 & 2.826 & 0.419 & 0.381 & 0.602 & 0.537 \\
\hline Australia & 1.152 & 9.983 & 28.232 & 9.748 & 1.000 & 3.312 & 0.000 & 1.000 & 1.000 & 1.000 \\
\hline Austria & 2.161 & 3.891 & 13.199 & 9.411 & 1.000 & 3.254 & 0.000 & 1.000 & 1.000 & 1.000 \\
\hline Bangladesh & 0.141 & 0.978 & 0.043 & 7.827 & 0.000 & 1.139 & 0.495 & 0.095 & 0.444 & 0.417 \\
\hline Belgium & 2.016 & 10.775 & 37.385 & 9.489 & 1.000 & 3.103 & 0.000 & 1.000 & 1.000 & 1.000 \\
\hline Benin & -0.802 & 8.385 & 0.649 & 7.677 & 0.038 & 1.493 & 0.660 & 0.010 & 0.093 & 0.000 \\
\hline Bolivia & -0.006 & 18.452 & 3.294 & 8.037 & 0.731 & 2.730 & 0.362 & 0.371 & 0.556 & 0.500 \\
\hline $\begin{array}{l}\text { Brazil } \\
\text { Burkina }\end{array}$ & 1.992 & 5.487 & 3.013 & 8.408 & 0.000 & 2.981 & 0.471 & 0.319 & 0.593 & 0.593 \\
\hline Faso & 1.722 & 4.348 & 0.181 & 6.544 & 0.000 & 2.251 & 0.535 & 0.060 & 0.380 & 0.269 \\
\hline Burundi & 2.796 & 10.079 & 0.346 & 6.425 & 0.000 & 1.817 & 0.700 & 0.000 & 0.130 & 0.019 \\
\hline Cameroon & 2.556 & 18.146 & 1.911 & 7.286 & 0.000 & 2.360 & 0.786 & 0.000 & 0.250 & 0.157 \\
\hline $\begin{array}{l}\text { Canada } \\
\text { Central } \\
\text { African }\end{array}$ & 2.189 & 9.588 & 25.410 & 9.702 & 1.000 & 3.189 & 0.000 & 1.000 & 1.000 & 1.000 \\
\hline Republic & -1.112 & 8.826 & 0.864 & 7.198 & 0.000 & 1.670 & 0.700 & 0.000 & 0.130 & 0.028 \\
\hline Chile & 0.263 & 14.879 & 7.640 & 8.773 & 0.577 & 2.901 & 0.490 & 0.171 & 0.389 & 0.194 \\
\hline China & 2.252 & 1.950 & 0.070 & 7.126 & 0.000 & 3.019 & 0.729 & 0.000 & 0.120 & 0.111 \\
\hline Colombia & 1.433 & 9.417 & 2.815 & 8.329 & 0.192 & 2.751 & 0.000 & 0.781 & 0.685 & 0.824 \\
\hline Congo & 1.737 & 7.630 & 0.880 & 8.026 & 0.000 & 2.224 & 0.757 & 0.000 & 0.139 & 0.074 \\
\hline Costa Rica & 0.131 & 19.346 & 7.798 & 8.652 & 0.154 & 2.848 & 0.000 & 1.000 & 1.000 & 1.000 \\
\hline Ivory Coast & -1.289 & 29.321 & 5.626 & 8.072 & 0.000 & 2.308 & 0.890 & 0.000 & 0.296 & 0.194 \\
\hline Cyprus & 3.604 & 14.406 & 11.320 & 8.761 & 1.000 & 3.283 & 0.000 & 0.943 & 0.704 & 0.833 \\
\hline $\begin{array}{l}\text { Denmark } \\
\text { Dominican }\end{array}$ & 1.585 & 9.858 & 45.426 & 9.616 & 1.000 & 3.196 & 0.000 & 1.000 & 1.000 & 1.000 \\
\hline Republic & 0.851 & 13.459 & 2.506 & 8.036 & 0.000 & 2.877 & 0.152 & 0.410 & 0.741 & 0.815 \\
\hline Ecuador & 1.639 & 10.561 & 1.980 & 8.164 & 0.731 & 3.132 & 0.205 & 0.533 & 0.648 & 0.546 \\
\hline Egypt & 2.226 & 7.320 & 0.707 & 7.669 & 0.000 & 1.635 & 0.576 & 0.005 & 0.398 & 0.315 \\
\hline El Salvador & -0.125 & 15.674 & 5.443 & 8.180 & 0.038 & 2.103 & 0.206 & 0.363 & 0.537 & 0.620 \\
\hline Finland & 2.661 & 7.018 & 22.095 & 9.412 & 1.000 & 3.521 & 0.000 & 1.000 & 0.843 & 0.861 \\
\hline France & 1.775 & 2.998 & 10.633 & 9.599 & 1.000 & 3.285 & 0.000 & 0.824 & 0.852 & 1.000 \\
\hline Gambia & 0.614 & 36.125 & 2.510 & 7.174 & 0.192 & 1.800 & 0.000 & 0.757 & 0.713 & 0.759 \\
\hline Germany & 1.678 & 2.181 & & 9.602 & 1.000 & 3.247 & 0.000 & 1.000 & 0.898 & 1.000 \\
\hline Ghana & -0.727 & 21.091 & 2.167 & 7.623 & 0.192 & 1.620 & 0.574 & 0.116 & 0.324 & 0.185 \\
\hline Greece & 2.139 & 4.087 & 5.907 & 8.795 & 1.000 & 3.201 & 0.140 & 0.690 & 0.769 & 0.796 \\
\hline Guatemala & 0.234 & 11.399 & 2.885 & 8.283 & 0.077 & 2.218 & 0.345 & 0.180 & 0.491 & 0.519 \\
\hline Honduras & 0.363 & 23.196 & 2.828 & 7.809 & 0.000 & 2.595 & 0.100 & 0.316 & 0.667 & 0.491 \\
\hline India & 1.987 & 1.648 & 0.077 & 7.268 & 0.000 & 2.653 & 0.000 & 0.814 & 0.657 & 0.833 \\
\hline Indonesia & 4.557 & 11.239 & 0.721 & 7.176 & 0.769 & 3.071 & 0.700 & 0.000 & 0.296 & 0.333 \\
\hline Iran & -1.908 & 11.946 & & 9.155 & 0.000 & 3.022 & 0.800 & 0.000 & 0.204 & 0.259 \\
\hline Ireland & 2.728 & 15.430 & 24.487 & 9.071 & 0.962 & 3.256 & 0.000 & 1.000 & 0.963 & 1.000 \\
\hline Israel & 2.219 & 3.985 & 7.249 & 9.207 & 0.192 & 3.199 & 0.000 & 0.900 & 0.778 & 0.833 \\
\hline Italy & 2.186 & 2.081 & 4.851 & 9.370 & 1.000 & 3.254 & 0.000 & 1.000 & 0.907 & 0.963 \\
\hline Jamaica & -1.350 & 13.681 & 5.200 & 8.626 & 0.385 & 2.937 & 0.000 & 1.000 & 0.731 & 0.880 \\
\hline Japan & 3.314 & 0.640 & 2.753 & 9.269 & 1.000 & 3.537 & 0.000 & 1.000 & 1.000 & 0.926 \\
\hline Jordan & 2.934 & 8.976 & 3.536 & 7.933 & 1.000 & 2.821 & 0.910 & 0.010 & 0.222 & 0.213 \\
\hline
\end{tabular}




\begin{tabular}{|c|c|c|c|c|c|c|c|c|c|c|}
\hline Kenya & 2.241 & 18.082 & 0.846 & 7.111 & 0.115 & 2.676 & 0.686 & 0.000 & 0.361 & 0.278 \\
\hline Korea & 5.706 & 2.242 & 1.049 & 8.031 & 0.846 & 3.295 & 0.540 & 0.145 & 0.306 & 0.435 \\
\hline Madagascar & -2.372 & 11.874 & 0.987 & 7.665 & 0.000 & 0.333 & 0.543 & 0.033 & 0.324 & 0.296 \\
\hline Malawi & 0.872 & 20.730 & 0.606 & 6.760 & 0.000 & 2.424 & 0.900 & 0.000 & 0.074 & 0.102 \\
\hline Mali & 1.418 & 8.383 & 0.444 & 6.677 & 0.077 & 1.772 & 0.700 & 0.000 & 0.130 & 0.019 \\
\hline Mauritania & -0.319 & 41.095 & 4.353 & 7.383 & 0.000 & 2.838 & 0.700 & 0.000 & 0.167 & 0.102 \\
\hline Mauritius & 3.388 & 29.484 & 7.662 & 8.405 & 1.000 & 2.340 & 0.000 & 0.943 & 0.769 & 0.806 \\
\hline Mexico & 1.063 & 2.413 & 1.494 & 8.990 & 0.154 & 2.839 & 0.438 & 0.081 & 0.556 & 0.556 \\
\hline Morocco & 1.589 & 11.000 & 2.008 & 7.930 & 0.231 & 2.417 & 0.833 & 0.000 & 0.398 & 0.472 \\
\hline $\begin{array}{l}\text { Netherlands } \\
\text { New }\end{array}$ & 1.246 & 15.127 & 54.311 & 9.596 & 1.000 & 3.149 & 0.000 & 1.000 & 1.000 & 1.000 \\
\hline Zealand & 0.513 & 17.748 & 47.359 & 9.662 & 0.154 & 3.169 & 0.000 & 1.000 & 1.000 & 1.000 \\
\hline Nicaragua & -3.094 & 19.390 & 3.281 & 8.473 & 0.000 & 2.501 & 0.521 & 0.063 & 0.380 & 0.315 \\
\hline Nigeria & 1.296 & 13.821 & 0.699 & 7.323 & 0.154 & 2.712 & 0.700 & 0.000 & 0.491 & 0.352 \\
\hline Norway & 2.924 & 10.317 & 34.541 & 9.459 & 1.000 & 3.481 & 0.000 & 1.000 & 1.000 & 1.000 \\
\hline Pakistan & 1.153 & 2.937 & 0.168 & 7.619 & 0.000 & 2.259 & 0.378 & 0.311 & 0.370 & 0.343 \\
\hline Paraguay & 1.580 & 9.705 & 2.178 & 7.930 & 0.038 & 2.742 & 0.733 & 0.029 & 0.296 & 0.343 \\
\hline Peru & -1.628 & 15.285 & 8.032 & 8.558 & 0.115 & 2.861 & 0.295 & 0.411 & 0.546 & 0.537 \\
\hline Philippines & 0.681 & 12.598 & 2.250 & 7.903 & 0.077 & 2.803 & 0.590 & 0.200 & 0.454 & 0.454 \\
\hline Portugal & 3.751 & 4.781 & 5.072 & 8.581 & 1.000 & 3.135 & 0.189 & 0.758 & 0.741 & 0.796 \\
\hline Rwanda & 0.864 & 11.368 & 0.625 & 7.158 & 0.000 & 1.548 & 0.686 & 0.014 & 0.213 & 0.111 \\
\hline $\begin{array}{l}\text { Senegal } \\
\text { Sierra }\end{array}$ & 0.248 & 13.522 & 1.792 & 7.667 & 0.000 & 1.630 & 0.448 & 0.124 & 0.491 & 0.444 \\
\hline Leone & -2.089 & 9.056 & 0.592 & 7.865 & 0.000 & 0.311 & 0.643 & 0.014 & 0.333 & 0.296 \\
\hline $\begin{array}{l}\text { Singapore } \\
\text { South }\end{array}$ & 5.770 & 2.619 & 3.504 & 8.559 & 1.000 & 3.584 & 0.400 & 0.200 & 0.343 & 0.417 \\
\hline Africa & -0.231 & 17.200 & 14.615 & 8.683 & 0.000 & 2.920 & 0.295 & 0.700 & 0.241 & 0.389 \\
\hline Spain & 2.115 & 2.988 & 5.215 & 9.150 & 1.000 & 3.221 & 0.194 & 0.700 & 0.676 & 0.769 \\
\hline Sri Lanka & 1.924 & 14.804 & 1.086 & 7.734 & 0.231 & 2.391 & 0.038 & 0.676 & 0.593 & 0.759 \\
\hline Sudan & -0.322 & 15.529 & 0.759 & 7.342 & 0.000 & 1.876 & 0.605 & 0.126 & 0.241 & 0.269 \\
\hline Sweden & 1.661 & 5.037 & 20.583 & 9.707 & 1.000 & 3.108 & 0.000 & 1.000 & 1.000 & 0.991 \\
\hline Switzerland & 0.993 & 2.467 & 19.450 & 9.894 & 1.000 & 3.363 & 0.000 & 1.000 & 1.000 & 1.000 \\
\hline Syria & 2.405 & 8.076 & 1.056 & 8.499 & 0.038 & 2.729 & 0.900 & 0.000 & 0.056 & 0.194 \\
\hline Taiwan & 5.771 & 2.226 & & 8.246 & 1.000 & 3.196 & 0.648 & 0.038 & 0.389 & 0.306 \\
\hline Thailand & 3.145 & 8.559 & 1.406 & 8.008 & 1.000 & 2.865 & 0.200 & 0.284 & 0.537 & 0.509 \\
\hline Togo & 0.473 & 19.072 & 1.551 & 7.057 & 0.000 & 2.910 & 0.700 & 0.000 & 0.185 & 0.056 \\
\hline $\begin{array}{l}\text { Trinidad } \\
\text { and Tobago }\end{array}$ & -0.006 & 8.306 & 3.549 & 9.450 & 0.000 & 2.573 & 0.000 & 0.833 & 0.852 & 0.907 \\
\hline Tunisia & 2.759 & 10.302 & 2.134 & 7.967 & 0.038 & 2.677 & 0.790 & 0.000 & 0.352 & 0.231 \\
\hline Turkey & 2.086 & 3.798 & 1.367 & 8.305 & 0.038 & 3.115 & 0.138 & 0.671 & 0.509 & 0.694 \\
\hline $\begin{array}{l}\text { Uganda } \\
\text { United }\end{array}$ & -0.802 & 26.551 & 1.317 & 7.157 & 0.077 & 0.924 & 0.542 & 0.105 & 0.231 & 0.204 \\
\hline $\begin{array}{l}\text { Kingdom } \\
\text { United }\end{array}$ & 1.985 & 2.632 & 6.757 & 9.517 & 1.000 & 2.897 & 0.000 & 1.000 & 1.000 & 1.000 \\
\hline States & 1.342 & 1.263 & 4.954 & 9.949 & 1.000 & 3.128 & 0.000 & 1.000 & 1.000 & 1.000 \\
\hline Uruguay & 0.594 & 9.100 & 7.604 & 8.782 & 0.000 & 2.663 & 0.468 & 0.337 & 0.472 & 0.463 \\
\hline Venezuela & -1.847 & 23.696 & 21.249 & 9.620 & 0.038 & 3.098 & 0.000 & 0.900 & 0.824 & 0.963 \\
\hline Zambia & -2.184 & 54.311 & 7.267 & 7.683 & 0.000 & 2.771 & 0.843 & 0.029 & 0.306 & 0.315 \\
\hline Zimbabwe & 0.016 & 16.607 & 2.301 & 7.717 & 0.000 & 2.699 & 0.310 & 0.465 & 0.324 & 0.361 \\
\hline
\end{tabular}




\section{Definitions:}

- Economic growth: The average annual growth of real GDP divided by the economically active population over the period 1970-1990; unit: percent; source: Penn World Tables, mark 5.6.

Note: Data are available at http://www.cid.harvard.edu/. A more detailed description of the data and some exceptions from the basic definition can be found in Sachs and Warner (1997), where this variable is called GEA7090.

- Primary exports share: The share of exports of primary products in GNP in 1970; primary products exports are exports of fuels and non-fuel primary products; both numerator and denominator are measured in nominal U.S. dollars; local currency GNP is converted to dollars using a smoothed exchange rate; unit: percent; source: World Bank (1995).

Note: Data are available at http://www.cid.harvard.edu/. A more detailed description of the data and some exceptions from the basic definition can be found in Sachs and Warner (1997), where this variable is called SXP.

- Primary exports per capita: Exports of primary products per capita in 1970; computed by multiplying Primary exports share with GNP per capita in 1970 measured in constant 1995 U.S. dollars and by multiplying the result with an appropriate constant so that the sample maximum of Primary exports per capita equals the sample maximum of Primary exports share; unit: 1995 U.S. dollars (times 46.4); source: World Bank (2000) for the 1970 GNP per capita.

Note: In some cases a different year than 1970 is chosen for the GNP per capita. The exceptions are in accord with the exceptions from the basic definition of Primary exports share as described in Sachs and Warner (1997).

- Log initial income: Natural logarithm of real GDP divided by the economically active population in 1970; unit: index; source: Penn World Tables, mark 5.6 for the real GDP and World Bank (1995) for the economically active population.

Note: Data are available at http://www.cid.harvard.edu/. A more detailed description of the data and some exceptions from the basic definition can be found in Sachs and Warner (1997), where this variable is called LGDPEA70.

- Openness: The fraction of years during the period 1970-1990 in which the country is rated as an open economy; unit: index; source: Sachs and Warner (1995b).

Note: Data are available at http://www.cid.harvard.edu/. In Sachs and Warner (1997), this variable is called SOPEN.

- Log Investment ratio: Natural logarithm of the ratio of real gross domestic investment (public plus private) to real GDP, averaged over the period 1970-1989; unit: index; source: Penn World Tables, mark 5.6.

Note: Data are available at http://www.cid.harvard.edu/. In Sachs and Warner (1997), this variable is called LINV7089.

- Autocracy: Average of the Polity IV variable AUTOC over the period 1970-1990 (for each country only the years with available data were used) rescaled to the range 0 to $1 ; 1$ indicates the highest and 0 the lowest level of autocracy; unit: index; source Polity IV Project (2001).

- Democracy: Average of the Polity IV variable DEMOC over the period 1970-1990 (for each country only the years with available data were used) rescaled to the range 0 to $1 ; 1$ indicates the highest and 0 the lowest level of democracy; unit: index; source Polity IV Project (2001).

- Civil liberties: Average of the Freedom House index of civil liberties over the period 1973-1990 (for each country only the years with available data were used) rescaled 
to the range 0 to $1 ; 1$ indicates the highest and 0 the lowest level of civil liberties; unit: index; source Freedom House (2002).

- Political rights: Average of the Freedom House index of political rights over the period 1973-1990 (for each country only the years with available data were used) rescaled to the range 0 to $1 ; 1$ indicates the highest and 0 the lowest level of political rights; unit: index; source Freedom House (2002).

Table A.3: Statistics on variables used in the Primary Exports Sample.

\begin{tabular}{|c|c|c|c|c|c|c|}
\hline Variable & Mean & Median & Max. & Min. & $\begin{array}{l}\text { Standard } \\
\text { deviation }\end{array}$ & Obs. \\
\hline Economic growth & 1.21 & 1.43 & 5.77 & -3.09 & 1.77 & 86 \\
\hline Primary exports share & 11.9 & 10.2 & 54.3 & 0.64 & 9.23 & 86 \\
\hline Primary exports p. cap. & 7.54 & 2.88 & 54.3 & 0.04 & 11.3 & 83 \\
\hline Log initial income & 8.32 & 8.25 & 9.95 & 6.43 & 0.91 & 86 \\
\hline Openness & 0.38 & 0.12 & 1.00 & 0.00 & 0.44 & 86 \\
\hline Log invest. ratio & 2.66 & 2.84 & 3.58 & 0.31 & 0.68 & 86 \\
\hline Autocracy & 0.36 & 0.37 & 0.91 & 0.00 & 0.32 & 86 \\
\hline Democracy & 0.43 & 0.32 & 1.00 & 0.00 & 0.41 & 86 \\
\hline Civil liberties & 0.54 & 0.50 & 1.00 & 0.06 & 0.30 & 86 \\
\hline Political rights & 0.55 & 0.50 & 1.00 & 0.00 & 0.33 & 86 \\
\hline
\end{tabular}

Table A.4: Correlations of variables used in the Primary Exports Sample.

\begin{tabular}{|c|c|c|c|c|c|}
\hline Variable & $\begin{array}{r}\text { Economic } \\
\text { growth }\end{array}$ & $\begin{array}{r}\text { Prim. exports } \\
\text { share }\end{array}$ & $\begin{array}{r}\text { Prim. exports } \\
\text { p. cap. }\end{array}$ & $\begin{array}{r}\text { Log initial } \\
\text { income }\end{array}$ & Openness \\
\hline Economic growth & 1.00 & & & & \\
\hline Primary exports share & -0.45 & 1.00 & & & \\
\hline Primary exports p. cap. & 0.05 & 0.03 & 1.00 & & \\
\hline Log initial income & 0.08 & -0.30 & 0.66 & 1.00 & \\
\hline Openness & 0.57 & -0.33 & 0.47 & 0.61 & 1.00 \\
\hline Log invest. ratio & 0.48 & -0.20 & 0.42 & 0.60 & 0.57 \\
\hline Autocracy & -0.14 & 0.21 & -0.51 & -0.68 & -0.54 \\
\hline Democracy & 0.17 & -0.19 & 0.62 & 0.76 & 0.62 \\
\hline Civil liberties & 0.17 & -0.22 & 0.63 & 0.79 & 0.63 \\
\hline \multirow[t]{2}{*}{ Political rights } & 0.19 & -0.23 & 0.60 & 0.80 & 0.62 \\
\hline & $\begin{array}{r}\text { Log invest. } \\
\text { ratio }\end{array}$ & Autocracy & Democracy & $\begin{array}{r}\text { Civil } \\
\text { liberties }\end{array}$ & $\begin{array}{r}\text { Political } \\
\text { rights }\end{array}$ \\
\hline
\end{tabular}

Economic growth

Prim. exports share

Prim. exports $p$. cap.

Log initial income

Openness

Log invest. ratio

Autocracy

Democracy

Civil liberties

1.00

$-0.42$

0.53

1.00

0.51

$-0.94$

0.54

$-0.90$

1.00

0.92

$-0.92 \quad 0.94$

1.00

0.97

1.00 


\section{References:}

Auty, R.M., 1997. Natural resources, the state and development strategy. Journal of International development, 9, 651-663.

Auty, R.M., 2001. The political economy of resource-driven growth. European Economic Review, 45, 839-846.

Barro, R.J., 1991. Economic growth in a cross section of countries. Quarterly Journal of Economics, 106, 407-444.

Barro, R.J., 1997. Determinants of economic growth: A cross-country empirical study. Cambridge, Massachusetts: MIT Press.

Barro, R.J., 1999. Determinants of democracy. Journal of Political Economy, 107, S159-S183.

Davis, G.A., 1995. Learning to love the Dutch disease: Evidence from the mineral economies. World Development, 23, 1765-1779.

Doppelhofer, G., Miller, R., Sala-i-Martin, X., 2000. Determinants of long-term growth: A Bayesian averaging of classical estimates (BACE) approach. NBER Working Paper, 7750 .

Easterly, W., 2001. The middle class consensus and economic development. Journal of Economic Growth, 6, 317-335.

Freedom House, 2002. Freedom in the world country ratings 1972-73 to 2001-2002. Available at: http://www.freedomhouse.org/.

Gelb, A., 1988. Oil windfalls: blessing or curse? New York, Oxford University Press.

Glaeser, E.L., La Porta, R., Lopez-de-Silanes, F., Shleifer, A., 2004. Do institutions cause growth? NBER Working Paper, 10568.

Gylfason, T., 2001a. Nature, power, and growth. Scottish Journal of Political Economy, 48, 558-588.

Gylfason, T., 2001b. Natural resources, education, and economic development. European Economic Review, 45, 847-859.

Gylfason, T., Zoega, G., 2002. Natural resources and economic growth: The role of investment. CEPR Discussion Paper, 2743.

Hanousek, J., Hajkova, D., Filer, R.K., 2004. The mirage of convergence: Why poor countries may only seem to be closing the income gap. CERGE-EI Working Paper, 222, Available at: http://www.cerge-ei.cz/.

Helliwell, J.F., 1992. Empirical linkages between democracy and economic growth. NBER Working Paper, 4066.

Levine, R., Renelt, D., 1992. A sensitivity analysis of cross-country growth regressions. American Economic Review, 82(4), 942-963.

Marshall, M.G., Jaggers, K., 2002. Political regime characteristics and transitions, 18002002, Data users' manual. Available at: http://www.cidcm.umd.edu/inscr/polity/.

McMahon, G., 1997. The natural resource curse: Myth or reality? Economic Development Institute, World Bank, Washington, D.C. 
Mehlum, H., Moene, K., Torvik, R., 2002. Institutions and the resource curse. Memorandum 29/2002, Department of Economics, University of Oslo. Available at: http://www.oekonomi.uio.no/memo/.

Mo, P., H., 2001. Corruption and economic growth. Journal of Comparative Economics, 29(1), 66-79.

Polity IV Project, 2001. Political regime characteristics and transitions, 1800-2001. Available at: http://www.cidem.umd.edu/inscr/polity/.

Papyrakis, E., Gerlagh, R., 2004. The resource curse hypothesis and its transmission channels. Journal of Comparative Economics, 32, 181-193.

Robinson, J.A., Torvik, R., Verdier, T., 2002. Political foundations of the resource curse. CEPR Discussion Paper, 3422.

Sachs, J.D., Warner, A.M., 1995a. Natural resource abundance and economic growth. NBER Working Paper, 5398.

Sachs, J.D., Warner, A.M., 1995b. Economic reform and the process of global integration. Brookings Papers on Economic Activity, 1995:1, 1-118.

Sachs, J.D., Warner, A.M., 1997. Natural resource abundance and economic growth. Center for International Development and Harvard Institute for Development, Harvard University, Cambridge MA. Available at: http://www.cid.harvard.edu/.

Sachs, J.D., Warner, A.M., 1999. The big push, natural resource booms and growth. Journal of Development Economics, 59, 43-76.

Sachs, J.D., Warner, A.M., 2001. The curse of natural resources. European Economic Review, 45, 827-838.

Sala-i-Martin, X., 1997. I just ran two million regressions. American Economic Review, 7, AEA Papers and Proceedings, May.

World Bank, 1995. World Data 1995. World Bank, Washington, DC.

World Bank, 1997. Expanding the measure of wealth: Indicators of environmentally sustainable development. Environmentally Sustainable Development Studies and Monographs Series No. 17, World Bank, Washington, DC.

World Bank, 2000. World Development Indicators 2000. World Bank, Washington, DC.

World Bank, 2003. World Development Indicators 2003. World Bank, Washington, DC. 
Individual researchers, as well as the on-line and printed versions of the CERGE-EI Working Papers (including their dissemination) were supported from the following institutional grants:

- Center of Advanced Political Economy Research [Centrum pro pokročilá politickoekonomická studia], No. LC542, (2005-2009),

- Economic Aspects of EU and EMU Entry [Ekonomické aspekty vstupu do Evropské unie a Evropské měnové unie], No. AVOZ70850503, (2005-2010);

- Economic Impact of European Integration on the Czech Republic [Ekonomické dopady evropské integrace na ČR], No. MSM0021620846, (2005-2011);

Specific research support and/or other grants the researchers/publications benefited from are acknowledged at the beginning of the Paper.

(c) Alexandr Černý, Randall K. Filer, 2007

All rights reserved. No part of this publication may be reproduced, stored in a retrieval system or transmitted in any form or by any means, electronic, mechanical or photocopying, recording, or otherwise without the prior permission of the publisher.

Published by

Charles University in Prague, Center for Economic Research and Graduate Education (CERGE) and

Economics Institute ASCR, v. v. i. (EI)

CERGE-El, Politických vězňů 7, 11121 Prague 1, tel.: +420 224005 153, Czech Republic.

Printed by CERGE-EI, Prague

Subscription: CERGE-EI homepage: http://www.cerge-ei.cz

Editors: Directors of CERGE and EI

Managing editors: Deputy Directors for Research of CERGE and EI

ISSN 1211-3298

ISBN 978-80-7343-120-4 (Univerzita Karlova. Centrum pro ekonomický výzkum

a doktorské studium)

ISBN 978-80-7344-109-8 (Národohospodářský ústav AV ČR, v. v. i.) 
CERGE-EI

P.O.BOX 882

Politických vězňů 7

11121 Praha 1

Czech Republic http://www.cerge-ei.cz 